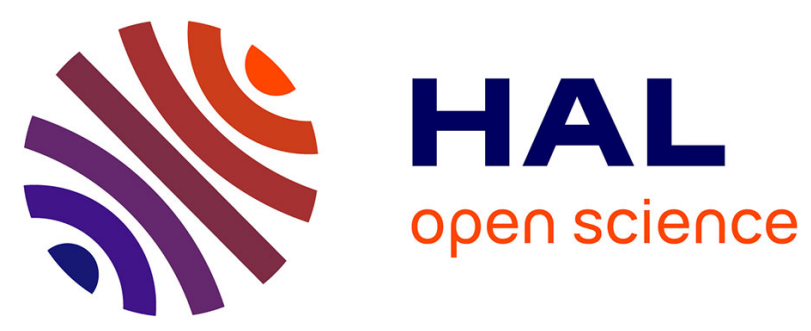

\title{
Marine protected areas Overall Success Evaluation (MOSE): A novel integrated framework for assessing management performance and social-ecological benefits of MPAs
}

F. Picone, E. Buonocore, Joachim Claudet, R. Chemello, G.F. Russo, P.P.

Franzese

\section{To cite this version:}

F. Picone, E. Buonocore, Joachim Claudet, R. Chemello, G.F. Russo, et al.. Marine protected areas Overall Success Evaluation (MOSE): A novel integrated framework for assessing management performance and social-ecological benefits of MPAs. Ocean and Coastal Management, 2020, 198, pp.105370. 10.1016/j.ocecoaman.2020.105370 . hal-03034197

\author{
HAL Id: hal-03034197 \\ https://hal.science/hal-03034197
}

Submitted on 1 Dec 2020

HAL is a multi-disciplinary open access archive for the deposit and dissemination of scientific research documents, whether they are published or not. The documents may come from teaching and research institutions in France or abroad, or from public or private research centers.
L'archive ouverte pluridisciplinaire HAL, est destinée au dépôt et à la diffusion de documents scientifiques de niveau recherche, publiés ou non, émanant des établissements d'enseignement et de recherche français ou étrangers, des laboratoires publics ou privés. 

A novel integrated framework for assessing management performance and social-ecological benefits of MPAs

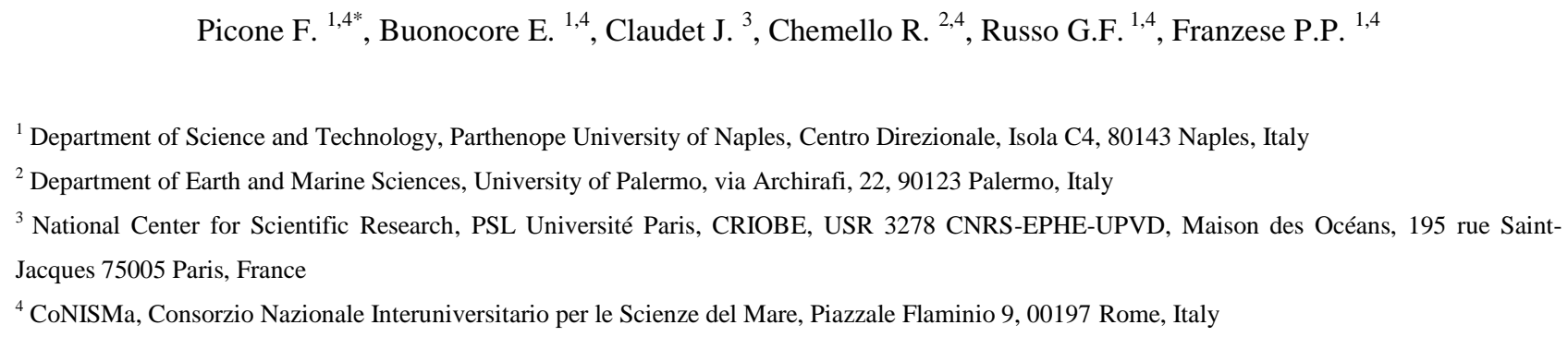

\section{Abstract}

Characterized by interlinked social, economic, and ecological dynamics, Marine Protected Areas (MPAs) are a management tool for achieving sustainability goals in social-ecological systems. The recent increase in their establishment worldwide, fostered by international policies, highlights the need for comprehensive and integrated assessment frameworks able to address the evaluation of their social-ecological effectiveness and management performance, which is of fundamental importance for their adaptive management and decision making processes. Although several indicators and methodologies exist to assess MPAs ecological or social performances, no comprehensive assessment framework currently captures their broad range of objectives, encompassing the ecological, socio-cultural, and economic spheres. In this study, we present a novel quantitative framework (named MPAs Overall Success Evaluation - MOSE) able to assess the overall effectiveness and management performance of MPAs under the perspective of socialecological systems. The multicriteria framework includes indicators linked to nature conservation, socio-cultural, socio-economic, and management objectives, integrating the multidisciplinary knowledge on MPAs in a single but comprehensive approach. The proposed framework was applied to the case study of Cerbère-Banyuls Natural Marine Reserve (France), the first MPA included in the IUCN Green List. Results showed that a high level of management effort is applied to the investigated MPA, generating several social-ecological benefits. This study showed the applicability of the MOSE framework and its potential usefulness as a tool to inform managers and decision-makers in charge for developing adaptive management strategies.

Keywords: marine protected areas; management performance; reserve effectiveness; multicriteria assessment framework; social-ecological systems.

* Corresponding author: flavio.picone@uniparthenope.it 


\section{Introduction}

In the last decades, particular emphasis has been placed upon the sustainable use of the global ocean (Claudet et al., 2020; IOC-UNESCO, 2017; UN, 2015). Close to 40 per cent of the world's population lives in coastal areas and relies on marine and coastal ecosystems for vital services such as food security, coastal protection, and employment in the fishing industry and tourist sector (Barbier, 2017). Nonetheless, ocean benefits to people go far beyond the coastal zone, involving the delivery of ecosystem services at the global scale such as carbon sequestration and climate regulation (Herr and Landis, 2016; Laffoley and Baxter, 2016; Nellemann et al., 2009). Direct and indirect human pressures like overfishing, pollution, urbanization, and climate change are synergically impacting marine natural capital jeopardizing the provisioning of these essential ecosystem services (Buonocore et al., 2018; Pauna et al., 2018; Worm et al., 2006). Considering the vital role of the oceans for human survival and well-being, effective policies and actions aiming at the sustainable use of marine natural capital are imperative.

The 2030 Agenda for Sustainable Development of the United Nations included the Sustainable Development Goal (SDG) 14 "Life below water" to face the challenge of the sustainable use of the ocean (UN, 2015). This Goal aims to "conserve and sustainably use the oceans, seas and marine resources for sustainable development" and shares with the Aichi Biodiversity Target 11 the objective of conserving at least the 10 per cent of coastal and marine areas by 2020 (UN, 2015; CBD, 2011). In this context, Marine Protected Areas (MPAs) are increasingly being established to protect and conserve marine natural capital, ecosystem services, and cultural values from the variety of anthropogenic threats on coastal and offshore marine ecosystems (Claudet, 2011). Characterized by interlinked social, economic, and ecological dynamics (Leenhardt et al., 2015a,b), MPAs represent complex conservation and management tools to support the achievement of sustainability goals in social-ecological systems (SESs) (López-Angarita et al., 2014; Pollnac et al., 2010; Zupan et al., 2018a). Marine sustainability studies have been showing an increasing interest towards the SESs approach (e.g., Adger et al., 2005; Berkes, 2011; Leenhardt et al., 2015b; Winter et al., 2018) due to its suitability to integrate natural and social sciences while addressing management issues involving ecosystems, human economy, and governance (Charles, 2012). The growing research on MPAs as sustainability tools has increasingly expanded from the sole ecological domain to also include social, health, cultural, and governance spheres (Bennet et al., 2017; Gill et al., 2017; Hogg et al., 2013; Mascia, 2004). MPAs are indeed expected to deliver social and economic benefits in addition to conserving biodiversity (Leenhardt et al., 2015a, Vihervaara et al., 2019; UNEPWCMC, IUCN and NGS, 2018). 
The many ecosystem services provided by MPAs contribute to human well-being in several ways

75 (Ban et al., 2019). MPAs can potentially reduce poverty by creating alternative livelihoods and new 76 jobs, especially in the tourism sector, and by increasing fish catches as a result of fishing spillover 77 from no-take zones (Beukering et al., 2014; Russ et al., 2004). By recovering fish stocks and 78 promoting more productive and sustainable fisheries, MPAs also improve food security of local communities that rely on such food sources (Mascia et al, 2010). In addition, when good governance is in place, MPAs foster equity through community participation to decision-making processes, empowering usually marginalized categories such as women and therefore promoting gender equality (Beukering et al., 2014; Jones et al., 2019). Moreover, by improving ecosystems health and resilience, MPAs play an important part in promoting climate change adaptation and mitigation (Otero et al., 2013; Simard et al., 2016). Finally, MPAs are also tools for scientific research and education. Indeed, they can serve as laboratories to enhance the understanding of the marine environment (Galzin et al., 2004) and can help raising the awareness of the public on marine sustainability issues (Angulo-Valdés and Hatcher, 2010; Brander et al., 2015). It is therefore evident that the well-being of coastal communities is influenced by the overall success of MPAs in the management of marine ecosystems and their resources. The contribution of MPAs to the sustainability of marine SESs follows a hierarchical pattern, in which socio-economic goals can be achieved only after the biophysical ones are met. Considering the abovementioned potential benefits and applying the classification of the United Nations

93 Sustainable Development Goals (SDGs) (UN, 2015), successful MPAs contribute to human well94 being supporting not only SDG14 "Life Below Water", but also SDGs 1 "No Poverty", 2 "Zero 95 Hunger", 3 “Good Health and Well-Being", 4 "Quality Education", 5 "Gender Equality", 8 "Decent 96 Work and Economic Growth", 10 "Reduced Inequalities", 12 "Responsible Consumption and Production", and 13 "Climate Action" (Fig.1). 


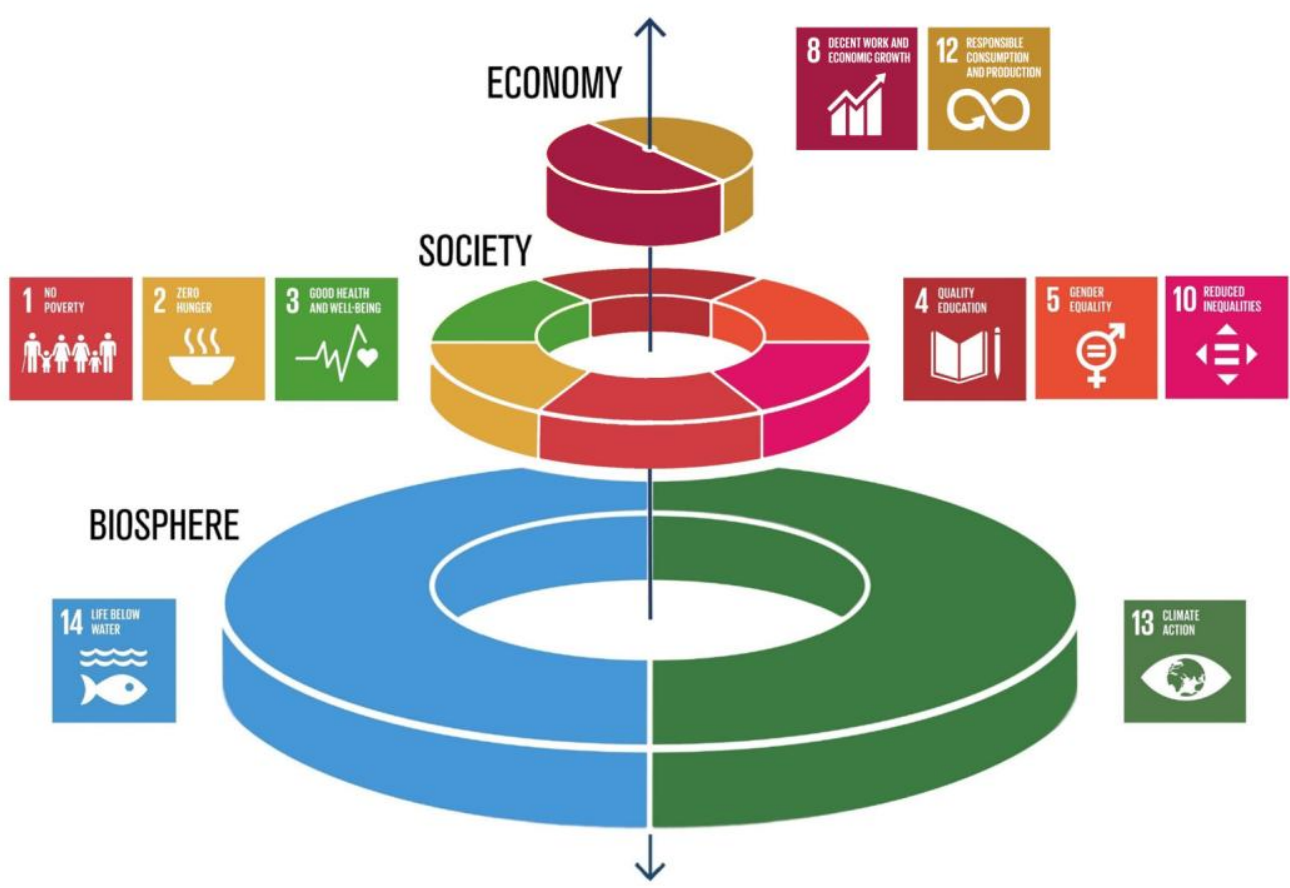

Figure 1. Modified version of the Sustainable Development Goals (SDGs) cake model showing the SDGs supported by MPAs: 1 "No Poverty", 2 "Zero Hunger", 3 "Good Health and Well-Being", 4 "Quality Education", 5 "Gender Equality", 8 "Decent Work and Economic Growth", 10 "Reduced Inequalities", 12 "Responsible Consumption and Production",13 "Climate Action", 14 "Life Below Water".

Of course, the implementation of MPAs entails costs besides benefits. Recent findings show that a global expansion of MPAs can generate economic benefits almost three greater than costs (Brander et al., 2020). Nonetheless, the establishment of MPAs should be complemented by cost-benefit analysis to understand the social, economic and environmental implications involved.

To promote the achievement of MPA sustainability goals and the delivery of the expected benefits to ecosystems and human well-being, the implementation of holistic and integrated socialecological assessments is much needed (Agardy et al., 2016; Ojeda-Martinez et al., 2009; Rasheed, 2020). Despite the considerable growth of the science of MPAs in the last years, the challenge of how assessing and promoting MPA success still persists (Bennett and Dearden, 2014; Giakoumi et al., 2018). To comprehensively evaluate the effectiveness of MPAs, assessment frameworks need to integrate multiple variables and explore new frontiers of study such as environmental accounting studies (Buonocore et al., 2019; Brander et al., 2020; Franzese et al., 2015, 2017, 2019; Picone et al., 2017; Roncin et al., 2008; Unsworth et al., 2010) and organization science (Scianna et al., 2015, 2018, 2019). Such frameworks require the identification of multidisciplinary success criteria and related measurable indicators suited to the social-ecological context of MPAs (Claudet, 2018; Claudet and Guidetti, 2010). Several indicators and methodologies can be found in the literature to assess their ecological, socio-economic, and management effectiveness (e.g., Bennett and Dearden, 
2014; Gallacher et al., 2016; Pelletier et al., 2005; Pomeroy et al., 2005; Rodríguez-Rodríguez et al.

123 2016). Nonetheless, too often MPAs are only assessed along one dimension of sustainability while 124 the others are neglected, as it has been historically the case of the social domain (Bennet et al., 125 2017; Claudet and Guidetti, 2010; Pelletier, 2011). This can lead to a false sense of success, for 126 instance when MPAs are an ecological success but a social failure (Christie, 2004). To holistically 127 assess MPA success, biophysical, socio-economic, and governance indicators need to be coherently 128 integrated (Gallacher et al., 2016). In addition to these domains of investigation, fundamental is the 129 evaluation of MPAs management effectiveness, which remains one of the main issues in MPA science (Scianna et al., 2019). Existing frameworks usually focus on just one or few of these domains and fields, providing partial information on MPA outcomes (Tab. 1).

Table 1. Examples of available MPA assessment frameworks. For each one, domain of assessment, authors, and year of release are reported.

\begin{tabular}{|c|c|c|c|}
\hline Framework name or subject & Domain of assessment & Authors & Year \\
\hline $\begin{array}{c}\text { Rapid Assessment and Prioritization of Protected } \\
\text { Area Management (RAPPAM) }\end{array}$ & Management & WWF & 2003 \\
\hline MPA Management Effectiveness & Management & Pomeroy & 2005 \\
\hline Management Effectiveness Tracking Tool (METT) & Management & WWF & 2007 \\
\hline DPSIR framework applied to MPAs & Management & $\begin{array}{l}\text { Ojeda-Martínez et } \\
\text { al. }\end{array}$ & 2009 \\
\hline $\begin{array}{l}\text { MPA Management Effectiveness Assessment Tool } \\
\text { (MEAT) }\end{array}$ & Management & MSN & 2010 \\
\hline $\begin{array}{c}\text { Integrated MPA Socio-Economic Assessment } \\
\text { (IMPASEA) }\end{array}$ & Socio-economic & $\begin{array}{l}\text { Rodríguez- } \\
\text { Rodríguez et al. }\end{array}$ & 2015 \\
\hline Protected Area Management Effectiveness (PAME) & Management & Hockings et al. & 2015 \\
\hline $\begin{array}{c}\text { Marine Protected Area Protection Assessment } \\
\text { Framework (MaPAF) }\end{array}$ & Management & $\begin{array}{l}\text { Rodríguez- } \\
\text { Rodríguez et al. }\end{array}$ & 2016 \\
\hline Socio-Economic Assessment Tool (SEAT) & Socio-economic & Rosales & 2018 \\
\hline Management Performance Index (MPI) & Management & Scianna et al. & 2018 \\
\hline IUCN Global Standard for MPAs & $\begin{array}{l}\text { Governance; management; } \\
\text { socio-economic; biophysical }\end{array}$ & IUCN & 2018 \\
\hline $\begin{array}{l}\text { Sustainability Evaluation of Marine Protected } \\
\text { Areas Index (SEMPAI) }\end{array}$ & $\begin{array}{l}\text { Biophysical; socio-economic; } \\
\text { governance }\end{array}$ & Avelino et al. & 2019 \\
\hline
\end{tabular}


Identifying and coherently integrating biophysical, socio-economic, governance, and management indicators in a single assessment framework is pivotal to support MPA success. By providing critical information on the main gaps to achieve MPA goals, effectiveness assessments can feed MPA management and decision-making processes supporting the implementation of ad hoc measures to improve the delivery of the expected social-ecological benefits. When possible, the information should be quantitative and science-based (Pelletier, 2011). The periodic repetition of the assessment provides fundamental insights on the system's response to the measures implemented, feeding back the management process for further decision-making. The negative feedback loop of the iterated steps "assessment-information-management-countermeasure" acts then as a single process, forming an adaptive management cycle (Fig. 2).

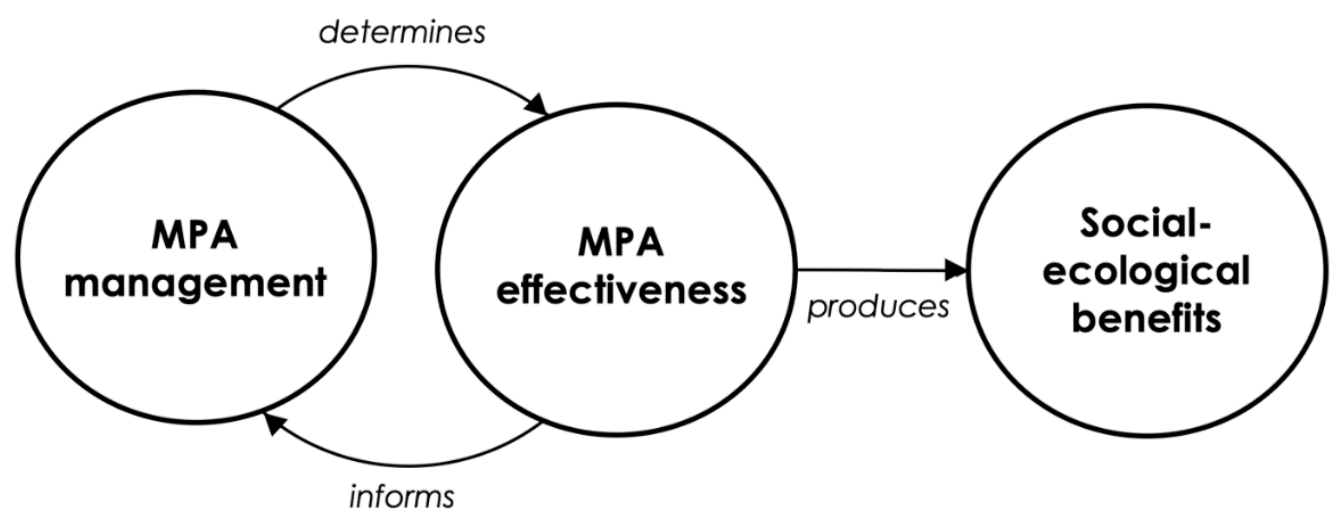

Figure 2. Flow diagram showing the relationships among MPA management, effectiveness, and relative social-ecological benefits.

In this study, we present a novel quantitative framework (named MPAs Overall Success Evaluation - MOSE) aimed at assessing the social-ecological effectiveness and management performance of MPAs under the perspective of SESs. This multicriteria assessment framework includes indicators linked to nature conservation, socio-economic, governance and management objectives, responding to the call for a multidisciplinary approach to the study of MPAs. In addition, to verify its applicability and potential usefulness, the MOSE framework is applied to the case study of CerbèreBanyuls Natural Marine Reserve (France), the first MPA included in the IUCN Green List of Protected and Conserved Areas.

\section{Materials and methods}

\subsection{The MPAs Overall Success Evaluation (MOSE) framework: structure and indicators}

The development of the MOSE framework has been inspired by the Ocean Health Index (OHI) (Halpern et al., 2012). Differently from the OHI, the MOSE framework is articulated in two main 
assessment domains and related indices in turn based on two different sets of indicators and subindicators, namely the Reserve Effectiveness Assessment (REA) and the Management Performance Assessment (MaPA). With "reserve effectiveness" we refer to the plurality of social-ecological benefits achieved by MPAs. Instead, according to Horigue et al. (2014) and Scianna et al. (2018), with "management performance" we refer to the "level of effort exerted to enhance and sustain the management of MPAs".

\subsubsection{Reserve Effectiveness Assessment (REA)}

A number of ecological and social-economic benefits are expected from the establishment of MPAs (Ban et al., 2019; Pelletier et al., 2005). Through conservation, fishing, economic, and cultural indicators, the Reserve Effectiveness Assessment (REA) index addresses the evaluation of the social-ecological reserve effect, which is expected to occur when MPAs are successfully managed. The selected indicators (and sub-indicators) are: 1) Biodiversity (Habitats and Species), 2) Fishing (Industrial fishing, Artisanal fishing, and Recreational fishing), 3) Local economy (Livelihoods, Tourism and recreation, and Natural products), and 4) Cultural identity (Charismatic species and Traditional activities) (Tab. 2). The score for each indicator is calculated as the ratio between the value of the measured variable inside the MPA and the value of the same variable in the outside control area. In the case of multi-use (or multiple-use) MPAs (i.e., MPAs where multiple uses are regulated with different restrictions according to the protection zone), REA indicators are evaluated for each protection zone, with the exception of the sub-indicators Livelihoods and Tourism and recreation that are calculated at the MPA scale. Biodiversity, Fishing, and Cultural identity indicators measure variables that are indeed expected to show differences in the scores across the different zones. Variables such as the biomass of fishes or the catch per unit effort (CPUE) of artisanal fishing are predictably related to the degree of protection (i.e., activities allowed), and therefore the relative indicators are supposed to show different outcomes. On the contrary, the Livelihoods and the Tourism and recreation sub-indicators target variables that respond to the overall performance of the MPA, and the evaluation of their benefits on local communities could not be unambiguously attributed to single zones where human activities occur. Finally, to calculate the REA score of the MPA, the scores of the protection zones are averaged weighting them by the area occupied by each zone in the MPA.

\subsubsection{Management Performance Assessment (MaPA)}


Besides the Reserve Effectiveness Assessment (REA), to evaluate MPAs not only as SESs but also 198 as management tools, the MOSE framework includes the Management Performance Assessment 199 (MaPA) index. The MaPA index targets management objectives that are acknowledged to be 200 fundamental to the success of MPAs, encompassing financial, social acceptance, information, 201 organization, and communication aspects. The achievement of such objectives is assessed through 202 the following indicators: 1) Level of surveillance, 2) Information and awareness of regulations, 3) 203 Stakeholders engagement, 4) Monitoring and reporting, 5) Financial support, 6) Professionalism 204 and competences, 7) Personnel stability, 8) Cultural heritage, and 9) Social media communication 205 (Tab. 2). Differently from the approach adopted in the REA, which compares inside vs outside 206 values, the MaPA index uses a scorecard approach to calculate the scores of its indicators.

Table 2. Indicators of Reserve Effectiveness Assessment (REA) and Management Performance Assessment (MaPA) composing the MOSE framework.

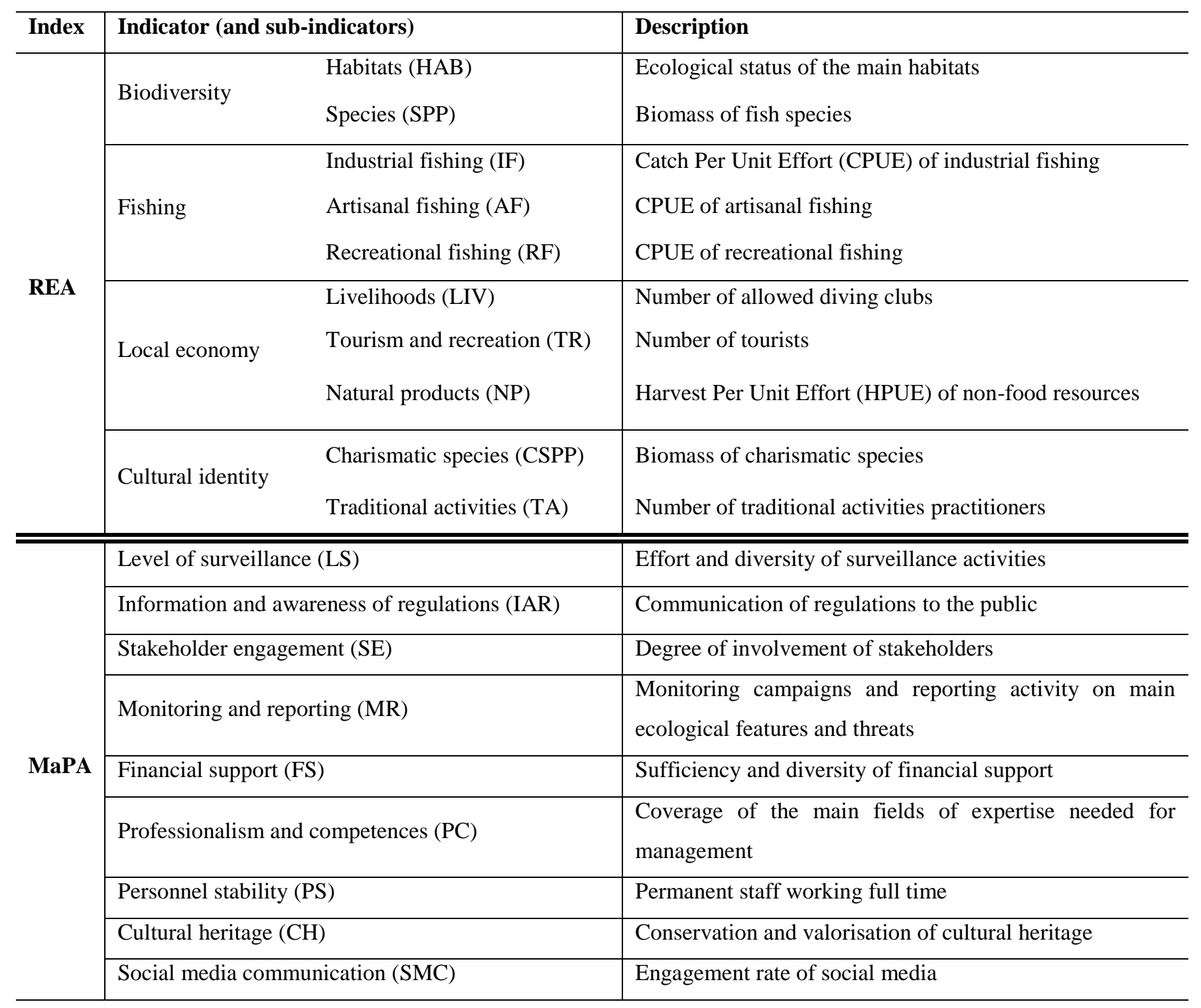


211 A detailed description of the abovementioned indicators, including the rationale behind their choice 212 and the full calculation method, is provided in section 2.4.

\subsection{Score calculation}

The overall scores of REA and MaPA are calculated as the average of the scores of their indicators:

$$
\text { REA, MaPA }=\sum_{i=1}^{\mathrm{N}} \frac{\mathrm{I}_{\mathrm{i}}}{\mathrm{N}}
$$

where $I_{i}$ is the score of the $i$-th indicator and $N$ is the number of indicators evaluated (Table 2). Each indicator $\left(I_{i}\right)$ is valued on a dimensionless scale from 0 to 100 . When indicators score more than 100 , the value of 100 is assigned.

\subsection{Complementary indicators}

The two proposed indices REA and MaPA included in the MOSE framework synthetically integrate information pertaining to different domains. To better interpret their results, two complementary indicators are proposed, the Protection level and the Degree of reliability.

The Protection level (PL) indicator supports the interpretation of REA results. Multi-use MPAs have different regulations in their protection zones and therefore differences in the social-ecological outcomes are to be expected. Based on regulations of uses and relative potential impacts on biodiversity, Horta e Costa et al. (2016) developed a classification system that unambiguously scores MPAs as well as each MPA zone individually. The protection level is expressed in a range from 1 (i.e., highest protection) to 8 (i.e., lowest protection) classified into 5 protection levels: unprotected, poorly protected, moderately protected, highly protected, and fully protected. Such classification method has been applied to a number of MPAs worldwide (Horta e Costa et al., 2016), then used to carry a global meta-analysis of the ecological effectiveness of partially protected areas (PPAs) of MPAs (Zupan et al., 2018b), and also suggested as a tool to support the assessment of protection levels in the context of international marine conservation targets (Claudet, 2019; Devillers et al., 2019).

238 The Degree of reliability $(D R)$ indicator is included in the MOSE framework to allow for applications even when data are partially lacking and not all indicators can be assessed. It is unlikely that MPA management bodies collect all the ecological, organizational, and management data needed to perform integrated analyses (Guidetti et al., 2014). Therefore, a reliability indicator of such assessments would provide useful information. The DR indicator is calculated for both the 
244 This information expresses the consistency of the overall indices scores, suggesting the 245 comprehensiveness level of the assessments.

\subsection{Rationale behind indicators and calculation methods}

\subsubsection{Biodiversity}

250 Historically, MPAs have been established with the main goal of conserving marine biodiversity, 251 anticipating positive ecological effects on species and habitats. Assessing and keeping track of the extent to which biodiversity goals are achieved are crucial steps to inform the adaptive management

\section{Sub-indicator: Habitats (HAB)}

The establishment of MPAs is expected to have positive impacts on the status of marine and coastal habitats (Ban et al., 2019; Pelletier et al., 2005). As a general rule, habitats in good status are more likely to harbor higher biodiversity than disturbed habitats, maintain their ecological functions, and support the delivery of ecosystem services (Cardinale et al., 2012; Vihervaara et al. 2019). Habitats are valuable not only from an ecological perspective, but also for recreational, aesthetic, sanitary, and existence reasons.

Fostered by European policies such as the Water Framework Directive (WFD - 2000/60/EC) and the Marine Strategy Framework Directive (MSFD - 2008/56/EC), the interest in the development of indexes of habitat quality has been increasing in the last years. Such indexes are built to represent an ecological quality target for selected habitats and are often used as proxy of environmental status, thus supporting monitoring and managing coastal environments (Borja et al., 2009). Biotic indexes can integrate information at species or community levels, assessing parameters such as abundance and diversity of sensitive and tolerant taxa. Most assessments classify habitat quality in five Ecological Status Classes (ESCs): High, Good, Moderate, Poor, and Bad.

The Habitats $(H A B)$ sub-indicator assesses the reserve effect on MPA habitats by comparing the ESCs evaluated in the different protection zones versus the ESCs outside the MPA according to the following formula:

$$
\mathrm{Hab}=\frac{1}{\mathrm{~N}} \sum_{\mathrm{j}=1}^{\mathrm{N}}\left(\frac{\mathrm{C}_{\mathrm{ji}}}{\mathrm{C}_{\mathrm{jo}}}-1\right) \times 100
$$
where, $C j i$ and $C j o$ are the values associated to the ESC of the $j$-th habitat, inside $(i)$ the investigated protection zones and outside (o) the MPA, and $N$ is the number of habitats assessed. 
277 When full protection measures are actually enforced, an increase in abundance, size, and biomass of previously fished assemblages is expected to occur (Guidetti, 2002; Claudet et al., 2008). The increase in size and density of fishes at upper trophic levels, mainly targeted by fishing activities, leads to cascading effects bringing community-wide ecological benefits (Claudet et al., 2011; Filbee-Dexter, 2014; Guidetti, 2006; Prato et al., 2013). In the case of partially protected zones where fishing occurs with restrictions, such benefits are significantly lower or even absent, showing more similarities to open access fished areas (Di Franco et al., 2009). For the Species (SPP) subindicator, the biomass of fish assemblages in the protection zones versus outside the MPA is compared, as it is commonly considered the most responsive indicator of the effect of protection on fish assemblages (Guidetti et al., 2014). Biomass is calculated based on abundance and size data of fish assemblages collected by means of visual census sampling techniques (Harmelin-Vivien et al., 1985).

289 The sub-indicator is then calculated as follows:

$$
\mathrm{SPP}=\frac{1}{\mathrm{~N}} \sum_{\mathrm{j}=1}^{\mathrm{N}}\left(\frac{\mathrm{B}_{\mathrm{i}}}{\mathrm{B}_{\mathrm{o}}}-1\right) \times 100
$$

where, $B_{i}$ and $B_{o}$ are the average biomasses per unit area of the $j$-th species, inside $(i)$ the evaluated protection zone and outside $(o)$ the MPA, and $N$ is the total number of species assessed.

\subsubsection{Fishing}

294 Sub-indicators: Industrial fishing (IF), artisanal fishing (AF), and recreational fishing (RF) Fisheries are an important source of food, livelihoods and incomes for hundreds of millions of people globally (FAO, 2016). Recent estimations on the world's fish stocks state that about $30 \%$ of them are fished at a biologically unsustainable rate (i.e., overfished) and almost $60 \%$ are fully exploited (i.e., fished close to their maximum sustainable yield) (FAO, 2016). Consequences of overfishing are vast, including the ecological, social, and economic spheres. The need for moving towards a sustainable use of fish resources has led to the Ecosystem Approach to Fisheries (EAF), which identifies principles and guidelines for the sustainability of fisheries management, explicitly linking human and ecosystem health (Garcia et al., 2003 Coll et al. 2013). This approach recognizes the important role that MPAs have in the sustainable management of the linked fisheries-marine resources system through the restrictions of fishing activities inside their boundaries. MPAs regulations aim at protecting and conserving marine biodiversity and, at the same time, enhance local fisheries by promoting a sustainable use of fish resources (Di Franco et al., 2016). 307 Theoretically, the reserve effect on fish assemblages (i.e., increase in size, abundance, and biomass) 
should lead to spillover phenomena from no-take to buffer zones when the carrying capacity of fish populations is reached. Similarly to the assessment of the reserve effect on fished species, the benefits of MPAs on fisheries could be evaluated by comparing values of catch per unit efforts (CPUEs) in fished protected zones versus outside unprotected areas. According to this approach, the reserve effect on industrial, artisanal, and recreational fishing activities is assessed through the following formula:

$$
\mathrm{IF}, \mathrm{AF}, \mathrm{RF}=\frac{1}{\mathrm{~N}} \sum_{\mathrm{j}=1}^{\mathrm{N}}\left(\frac{\mathrm{CPUE}_{\mathrm{i}}}{\mathrm{CPUE}_{\mathrm{o}}}-1\right) \times 100
$$

where $C P U E_{i}$ and $C P U E_{o}$ are the catches per unit effort of the $j$-th fishing techniques inside $(i)$ and outside $(o$ ) the MPA, and $N$ is the total number of fishing techniques assessed.

\subsubsection{Local Economy}

Extractive activities (i.e., fishing and harvest of non-food resources) and tourism are sectors driving the local economy of coastal communities, representing important sources of economic growth and jobs (European Commission, 2018; FAO, 2016). Through the regulations of human activities, MPAs influence local coastal economies that rely on ecosystem services generated by marine and coastal environments. Although less investigated in the literature compared to the ecological ones, impacts of the establishment of MPAs on the local economy are well-known and deserving of as much attention, especially under a SES perspective (Ojea et al., 2017). Economic benefits result from increasing tourist visits leading to higher revenues, increased jobs, and additional livelihood opportunities (European Commission, 2018). The Local economy indicator is composed of three sub-indicators: Livelihoods, Tourism and recreation, and Natural products.

\section{Sub-indicator: Livelihoods (LIV)}

The establishment of MPAs is generally linked to increases in jobs and/or incomes in commercial and tourism sectors, driven by those activities that benefit from the positive ecological impacts of protection on marine ecosystems, e.g. commercial fishing and recreational scuba diving (Alban et al. 2011; Pascual et al., 2016; Roncin et al., 2008). The most direct way to approach an evaluation of the economic impacts of MPAs on local coastal communities would be to collect and analyze data on net income of their activities. Nonetheless, this process could be challenging as entrepreneurs of these activities may be reluctant to share such sensitive data. The employment rate in the diving sector is suggested as one of the potential measures of the impacts of MPAs on local economy, as a consequence of the increase of diver visits (Ojea et al., 2017). For the Livelihoods (LIV) sub-indicator, we used the number of diving clubs in a $10 \mathrm{~km}^{2}$ radius as a proxy of the 
employment rate in the sector. This buffer area was calculated considering dive boats speed limits and usual length of dives. To assess the score, the number of diving clubs is divided by the considered coast length and then compared to the outside value, according to the formula:

$$
\operatorname{LIV}=\frac{\mathrm{d}_{\mathrm{i}}}{\mathrm{d}_{\mathrm{o}}} \times 100
$$

where $d_{i}$ is the number of diving clubs per unit of coast length in the buffer area or authorized by the MPA (if MPA regulations foreseen a maximum number of authorizations) and $d_{o}$ is the number of diving clubs per unit of coast length outside the MPA. Except from the number of authorized diving clubs, data to calculate the indicator are not supposed to be in possession of the MPA and are therefore collected independently.

\section{Sub-indicator: Tourism and recreation (TR)}

Nature-based tourism and recreational activities constitute the main attractions of MPAs (Leenhardt et al., 2015; Roncin et al., 2008) and their establishment is expected to have a positive impact on tourist visits (Pascual et al., 2016). Tourism and recreation affect the overall economy of coastal communities, including hotels and restaurants sectors and non-tourism aspects such as the increase of the local real estate values and the improvement of community infrastructure (European Commission, 2018). To account for the increase in the number of tourists in the MPA, different indicators can be used, e.g., tourist arrivals and accommodation capacities, depending on available data. The Tourism and recreation (TR) sub-indicator compares data on the number of beds between the MPA area of influence and reference comparable areas. Its score is calculated as follows:

$$
\mathrm{TR}=\frac{\mathrm{T}_{\mathrm{i}}}{\mathrm{T}_{\mathrm{O}}} \times 100
$$

where $T_{i}$ and $T_{o}$ are the number of beds in the MPA area of influence and in the control area placed outside the MPA. Data to calculate the indicator are not supposed to be in possession of the MPA and are therefore collected independently.

\section{Sub-indicator: Natural products (NP)}

MPAs can have an important role in the provisioning of natural products, i.e., non-food marine resources for manufactured products (sensu Halpern et al., 2012), which can be relevant components of the economies of coastal communities. The Natural products (NP) sub-indicator evaluates the artisanal and/or industrial Harvest Per Unit Effort (HPUE) of resources such as coral, marine plants, shells, and sponges, according to the formula: 


$$
\mathrm{NP}=\frac{1}{\mathrm{~N}} \sum_{\mathrm{j}=1}^{\mathrm{N}}\left(\frac{\text { HPUE }_{\mathrm{i}}}{\text { HPUE }_{\mathrm{o}}}-1\right) \times 100
$$

369

370

371

372

373

374

375

376

377

378

379

380

381

382

383

384

385

386

387

388

389

390

391

392

393

where, $H P U E_{i}$ and $H P U E_{o}$ are the harvests per unit effort of the $j$-th product inside and outside the MPA, and $N$ is the total number of products assessed.

\subsubsection{Cultural identity}

The local human component of MPAs is significantly connected to its territory, traditions and history. Communities place a high value to activities passed through generations (e.g., artisanal fishing), local species and culturally important places, being evidence of their cultural identity and heritage. MPAs could represent a shelter for such cultural features, whose existence and protection may be valued also by non-local people. According to definitions in Gee et al. (2017), MPAs can be considered culturally significant areas, as they "contain several culturally significant features to which one or more community have a significant connection". From this perspective, besides the traditional function of protecting and conserving their ecological features, MPAs may play an important role in the preservation of the cultural identity of local coastal communities.

The Cultural identity indicator is composed by two sub-indicators: Charismatic Species and Traditional activities.

\section{Sub-indicator: Charismatic species (CSPP)}

The concept of charismatic species is frequently used in conservation biology, even if it is poorly defined compared to other categories of focal species (Ducarme et al., 2012). Here, we refer to charismatic species as the ones that hold existence, aesthetic, or tradition-related values for the local coastal culture, inspiring a sense of belonging and identity in the local communities (Ducarme et al., 2012). The Charismatic species (CSPP) sub-indicator is calculated as the reserve effect on the biomass of charismatic species (or density in case of species more appropriately assessed through the number of individuals rather than biomass, e.g. in the case of marine mammals or sea turtles), according to the following formula:

$$
\operatorname{CSPP}=\frac{1}{N} \sum_{j=1}^{N}\left(\frac{B_{i}}{B_{o}}-1\right) \times 100
$$

where, $B_{i}$ and $B_{o}$ are the average biomasses (or number of individuals) per unit area of the $j$-th species inside $(i)$ the evaluated protection zone and outside $(o)$ the MPA, and $N$ is the total number of species assessed.

Sub-indicator: Traditional activities (TA) 
Traditional activities are important cultural features of local communities. The knowledge of the environment embedded in such practices and its passing down across generations give them both ecological and cultural relevance. In marine environments, anthropization of the coasts, decrease in fish stocks, and competition with large-scale fishing are endangering the sustainability of artisanal or small-scale fisheries (Kolding et al., 2014). Artisanal fishing is a relevant traditional activity of coastal communities, being an important source of employment, food security, and income (FAO, 2016).

Through the regulations of extractive uses, MPAs represent a form of spatial management that can be a suitable tool to preserve the viability of artisanal fisheries, providing an environment in which they can thrive in accordance to sustainability goals, potentially creating "win-win" situations (Dalton, 2010; Di Franco et al., 2016). To assess the support MPAs provide to small-scale fisheries, the Traditional activities (TA) sub-indicator measures the number of artisanal fishers authorized by the MPA, compared to outside values (e.g., regional or national scales). The score is calculated according to the following formula:

$$
\mathrm{TA}=\frac{1}{\mathrm{~N}} \sum_{\mathrm{j}=1}^{\mathrm{N}}\left(\frac{\mathrm{A}_{\mathrm{i}}}{\mathrm{A}_{\mathrm{o}}}-1\right) \times 100
$$

where, $A_{i}$ and $A_{o}$ are the average number of people per unit of coast length practicing the $j$-th traditional activity inside $(i)$ the evaluated protection zone of the MPA and at a regional or national scale $(o)$, and $N$ is the total number of traditional activities assessed.

The sub-indicator can be adapted to local peculiarities, accounting for traditional activities occurring in the MPA other than artisanal fishing. Data to calculate the indicator may not be in possession of the MPA. In this case, missing data are collected independently.

\subsubsection{Level of surveillance (LS)}

The enforcement of regulations is one of the main social drivers determining the success of MPAs (Giakoumi et al., 2018). Where the level of enforcement is low, compliance of users and stakeholders with regulations can be easily undermined as rulebreakers are unlikely punished (Rife et al., 2013). In these cases, no positive ecological effects on marine ecosystems should be expected (Guidetti et al., 2008; Edgar et al., 2014). Enforcement represents more than just surveillance or patrolling activities. It can be depicted as a chain composed by technical/operative, social, legislative, and financial links (Arias et al., 2015, 2016). Nonetheless, surveillance is a key aspect of enforcement as it increases the probability of detecting offenses and its lacking can lead to poaching and social distrust about the MPA (López Ornat and Vignes, 2015). 
The Level of surveillance $(L S)$ indicator focuses on the evaluation of the main aspects affecting the effort deployed in the surveillance activity. It is based on Scianna et al. (2018) approach and the score is calculated according to the following formula:

$$
\mathrm{LS}=\left(\frac{\mathrm{AC}+\mathrm{M}+\mathrm{A}}{3}\right) \times \mathrm{T} \times 100
$$

where, $A C$ stands for "authority and cooperation", $M$ for "methods", $A$ for "area", and $T$ for "time". $A C$ assesses the legal powers of the MPA staff enforcement and the cooperation with police bodies. The presence of these features is valued 1 , and the absence 0 . The score of $A C$ is calculated as the mean of the two. $M$ refers to the methods used to perform surveillance. A set of available methods and technologies was identified according to López Ornat and Vignes (2015) and Scianna et al. (2018), and is composed by controls "at sea", "from land", "during daytime", and "at night", and through technologies such as "video camera", "radar", "vessel monitoring system", "night vision binocular", "camera with georeferenced position", "laser", and "drones". These methods are valued 1 if present and 0 if absent. Finally, the $M$ score is calculated as the average of controls and technologies values. A is calculated as the area under surveillance over the total area of the MPA. Different importance (i.e., weights) can be given to different zones, depending on their protection levels. The average of $A C, M$, and $A$ is then multiplied by $T . T$ refers to the time of surveillance, accounting for the type of surveillance body and the season. Surveillance bodies are of three types, i.e. "staff without legal power", "police", and "staff with legal power or staff cooperating with police", to which 1, 1.2, and 1.5 weights are given, respectively, to value more the active cooperation of legally powered staff and police bodies. Each surveillance body, if active, is then multiplied by the time ratio between the days of surveillance and the days in the two seasons, i.e. "summer" and "winter".

\subsubsection{Information and awareness of regulation (IAR)}

The enforcement of regulations does not depend merely on surveillance activity. An important part is played by the extent to which information on regulations is conveyed to the users and visitors. Ignorance and misinformation are indeed the main cause of offences inside MPAs (López Ornat and Vignes, 2015) as compliance can be expected only to rules people are aware of and understand. According to López Ornat and Vignes (2015), different practices are recommended to inform users and visitors. These practices are used to calculate the Information and awareness of regulations $(I A R)$ indicator as follows:

$$
\mathrm{IAR}=\frac{\mathrm{S}+\mathrm{AI}}{2} \times 100
$$


where, $S$ and $A I$ are the signage and active information scores. Each score is calculated averaging the presence (value $=1$ ) or absence (value $=0$ ) of three factors. The calculation of the signage score takes into account the presence of: 1) information panels on land, 2) buoys delimiting the "no-take zones", 3) internet website with explained zonation and rules. The active information considers if: 1) MPA staff distributes brochures with detailed regulation information, 2) MPA staff, in summer, meets the leisure boats on arrival and informs them about boating activity rules, 3 ) tourist operators inform visitors they bring in the MPA.

\subsubsection{Stakeholder engagement (SE)}

The involvement of stakeholders is recognized as a major factor affecting the success of MPAs (Claudet and Guidetti, 2010; Giakoumi et al., 2018; Guidetti et al, 2010). Well-managed engagement can facilitate learning and trust among stakeholders (Durham et al., 2014) as it helps mediating conflicts and favoring social compliance. This is particularly true in the case of certain stakeholders such as small-scale fisheries and local government for which well-managed engagement is crucial for MPA effectiveness (Beger et al., 2004; Di Franco et al., 2016). For these stakeholders, the need for assessing and monitoring the effectiveness of their engagement is essential.

Different levels of engagement with stakeholders can be identified, based on the influence they have on the success of the MPA, and corresponding to different levels and methods of interaction (Durham et al., 2014; Sterling et al., 2017). For the Stakeholder engagement (SE) indicator, we identify three levels, namely "inform", "consult", and "collaborate” (Durham et al., 2014):

1) "inform" defines a low level of engagement, in which stakeholders are adequately updated with tailored information;

2) "consult" defines an intermediate level of engagement, in which stakeholders are more engaged with a higher level of interaction resulting in feedback information;

3) "collaborate" defines a high level of engagement, in which the involvement of stakeholders can include decision-making.

Appropriate methods of interaction can be associated to the three levels of engagement (Durham et al., 2014). The appropriateness of the method to the target level of engagement for a given stakeholder category can be classified in: $\mathrm{H}=$ high, $\mathrm{M}=$ medium, $\mathrm{L}=$ low, $\mathrm{NA}=$ not appropriate. If different methods of engagement are adopted for a stakeholder, the most appropriate one is used for the evaluation. Examples of engagement methods and their level of appropriateness are shown in 
Table 3. Modified from Durham et al. (2014). The table shows the appropriateness of the engagement method. $\mathrm{H}=$ high; $\mathrm{M}=$ medium; $\mathrm{L}=$ low; $\mathrm{NA}=$ not appropriate.

\begin{tabular}{l|c|c|c}
\hline & Inform & Consult & Collaborate \\
\hline Website & $\mathrm{H}$ & $\mathrm{M}$ & $\mathrm{L}$ \\
\hline Social media & $\mathrm{H}$ & $\mathrm{L}$ & $\mathrm{L}$ \\
\hline Lectures & $\mathrm{H}$ & $\mathrm{M}$ & $\mathrm{H}$ \\
\hline Multi-stakeholder forums & $\mathrm{NA}$ & $\mathrm{M}$ & $\mathrm{H}$ \\
\hline $\begin{array}{l}\text { One-to-one meeting and } \\
\text { interviews }\end{array}$ & $\mathrm{NA}$ & $\mathrm{M}$ & $\mathrm{H}$ \\
\hline Town Hall meeting & $\mathrm{NA}$ & $\mathrm{L}$ & $\mathrm{H}$ \\
\hline Workshops & NA & $\mathrm{H}$ & $\mathrm{L}$ \\
\hline Questionnaires/surveys & NA & NA & $\mathrm{H}$ \\
\hline Practical demonstration & NA & NA & $\mathrm{H}$ \\
\hline Steering group & NA & & \\
\hline
\end{tabular}

The Stakeholder engagement (SE) indicator is calculated according to the following formula:

$$
\mathrm{SE}=\sum_{\mathrm{i}=1}^{\mathrm{N}} \beta_{\mathrm{i}} \frac{\mathrm{St}_{\mathrm{i}}}{\mathrm{N}} \times 100
$$

where, $\beta_{i}$ is the engagement appropriateness factor of the $i$-th category (not appropriate $=0$; low $=$ 0.3 ; medium $=0.6$; high $=1) ; S t_{i}$ is the representativeness score of stakeholder category $i$, calculated as the number of stakeholders engaged on the total of category $I ; N$ is the total number of stakeholder categories assessed.

\subsubsection{Monitoring and reporting (MR)}

The adaptive management approach requires that decisions are taken based on the most updated evaluations on the status of social and ecological features. To make these data available, it is crucial that well-designed and long-term scientific monitoring programs are in place and carried out consistently. This would allow to readily respond to pressures, state changes, and impacts on the components of the social-ecological systems, providing effectiveness and legitimacy of implemented regulations and management measures (López Ornat and Vignes, 2015). The Monitoring and reporting $(M R)$ indicator jointly addresses the evaluation of: 1) the effort put in the collection of data on the most context-important ecological features and threats through monitoring activities, and 2) the use of these data to produce public reports/scientific publications.

512 The monitoring assessment takes into account the continuity of monitoring campaigns, while the 513 reporting assessment considers both a measure of the quality of the product (i.e., type of report), 514 according to Scianna et al. (2018), and the continuity of the reporting activity. 
The indicator is calculated according to the following formula:

$$
M R=\frac{1}{2}\left(\sum_{i=1}^{M} \frac{m_{i} \alpha_{i}}{M}+\sum_{i=1}^{R} \frac{r_{i} \beta_{i} \gamma_{i}}{R}\right) \times 100
$$

where, $m_{i}$ is the presence of monitoring campaigns on the $i$-th feature (presence $=1$; absence $=0$ ); $\alpha_{i}$ is the "continuity factor" of monitoring campaigns on the $i$-th feature; $M$ is the total number of ecological features and threats to be monitored; $r_{i}$ is the presence of reports on data collected through monitoring campaigns on the $i$-th feature; $\beta_{i}$ is the "continuity factor" of reports produced on collected data on the $i$-th feature; $\gamma_{i}$ is the "communication impact factor" of these reports; and $R$ is the number of features monitored. The way $\alpha, \beta$, and $\gamma$ are calculated is showed in table 4 .

Table 4. The table shows the calculation method of the three factors $\alpha, \beta$, and $\gamma$ of the Monitoring and reporting indicator. For each factor, quantities or categories are converted to values from 0 to 1.1 .

\begin{tabular}{|c|c|c|c|}
\hline Factor & Unit & Quantity or category & Value \\
\hline \multirow{4}{*}{$\alpha$} & \multirow{4}{*}{$\begin{array}{l}\text { Number of monitoring campaigns in } \\
\text { the last } 5 \text { years }\end{array}$} & 0 & 0 \\
\hline & & 1 & 0.6 \\
\hline & & 2 & 0.7 \\
\hline & & 3 & 0.8 \\
\hline \multirow{3}{*}{$\beta$} & \multirow{3}{*}{ Number of reports in the last 5 years } & 4 & 0.9 \\
\hline & & 5 & 1 \\
\hline & & $>5$ & 1.1 \\
\hline \multirow{5}{*}{$\gamma$} & \multirow{5}{*}{ Communication method } & not reported & 0 \\
\hline & & internal reports & 0.6 \\
\hline & & communications and outreach & 0.8 \\
\hline & & $\begin{array}{l}\text { scientific papers without impact } \\
\text { factors and scientific reports }\end{array}$ & 1 \\
\hline & & scientific papers with impact factor & 1.1 \\
\hline
\end{tabular}

\subsubsection{Financial support (FS)}

Effective management requires that sufficient financial resources are available to the MPA to cover overall costs to support management teams and actions (Binet et al., 2015). Given financial constraints, the capacity of management to achieve MPA goals and objectives is threatened as basic management costs (such as staff hiring, monitoring, and research) cannot be carried out. The Financial support (FS) indicator aims to assess the availability of financial resources and the evenness of their distribution among their sources. The financial availability is calculated as the gap between the total amount of financial resources available to the MPA in the assessed year and the 
sum of the costs faced in the same year. Costs are here intended as the financial needs to operate in a basic management scenario, as defined by Binet et al. (2015). Such scenario takes into account four components: 1) administrative organization and planning; 2) administrative support for stakeholder engagement; 3) knowledge acquisition and environment monitoring; 4) control, regulation, and supervisory.

The diversity of financial sources is also an important factor that can affect the financial stability of MPAs. In case the main source is lacking or fails, other sources can help compensating. Several funding sources can be identified for MPAs: local, regional, and national governments, international donors and NGOs, private sector, and self-financing.

The Financial support $(F S)$ indicator is then calculated according to the following formula:

$$
\mathrm{FS}=\frac{\mathrm{F}_{\mathrm{t}}}{\mathrm{C}} \times \mathrm{J} \times 100
$$

where $F_{t}$ is the total amount of financial resources, $C$ is the overall costs expected for the basic management, and $\mathrm{J}$ is the evenness of distribution of $\mathrm{F}_{\mathrm{t}}$ among the financial sources calculated using the Shannon-Wiener diversity index.

\subsubsection{Professionalism and competences (PC)}

MPA management requires a multidisciplinary approach and cross-sectors expertise. Considering social-ecological targets and management needs of MPAs, an efficient staff would need to include experts in the fields of reserve management, natural sciences, fisheries science, communication, accounting, and technical support. The Professionalism and competences $(P C)$ indicator takes into account the presence of specialized staff in the main identified fields as well as their level of expertise. The indicator is calculated according to the following formula:

$$
P C=\sum_{i=1}^{N} \frac{F_{i}+E_{i}}{N} \times 100
$$

where, $F_{i}$ is the presence of a staff member expert in the $i$-th field (presence $=0.5$; absence $=0$ ); $E_{i}$ is the expertise score, calculated as the education, training, and working years of the most experienced staff member of the $i$-th field multiplied by $0.1 ; N$ is the total number of fields of expertise considered.

\subsubsection{Personnel stability (PS)}

The stability of MPA personnel over time is an important factor affecting the effectiveness of management actions. Among other benefits, such as improvements in efficiency of working relationships and management continuity, stability helps meeting social-ecological targets, usually 
characterized by long-term responses to protection. Such long-term responses need continuity and

566 consistency of management actions (Scianna et al., 2018). Following Scianna et al. (2018), the 567 Personnel stability (PS) indicator is calculated as follows:

$$
\mathrm{PS}=\frac{\mathrm{PE}}{\mathrm{FTE}} \times 100
$$

568 where, $P E$ is the number of full-time permanent employees, and FTE is the total number of full569 time employees.

\subsubsection{Cultural heritage $(\mathrm{CH})$}

572 As already stated for the Cultural identity indicator of the REA, cultural features may represent important elements of the identity of local coastal communities, carrying historical and traditional values and therefore heritage to pass through generations. Cultural heritage is considered the “cultural capital" of contemporary societies, "essential for promoting peace and sustainable societal, environmental, and economic development" (UNESCO, 2014).

577 Following UNESCO (2014), the Cultural heritage ( $\mathrm{CH}$ ) indicator aims at assessing: 1) the adoption 578 of "conservation and valorization" measures and 2) the promotion of activities to "raise awareness and education" on the cultural heritage of MPAs. Cultural heritage elements are identified through sites in the seascape that can be defined as "works of men, or the combined works of nature and man, and areas including archeological sites, which are of outstanding value from the historical, aesthetic, ethnological or anthropological point of view" (UNESCO, 2014). Examples can be natural monuments (e.g., caves, peculiar geological formations), and historical or archeological sites (e.g., prehistorical settlements, harbors, underwater shipwrecks, fish establishments). The score of the indicator is calculated as follows:

$$
\mathrm{CH}=\sum_{\mathrm{i}=1}^{\mathrm{N}} \frac{\mathrm{CV}_{\mathrm{i}}+\mathrm{AE}_{\mathrm{i}}}{2 \mathrm{~N}} \times 100
$$
where, $C V_{i}$ and $A E_{i}$ represent the presence of "conservation and valorization" measures and of activities aimed at "raising awareness and education" on the $i$-th cultural element, and $N$ is the total number of cultural elements considered. "Conservation and valorization" covers the adoption of specific legislation and concrete measures or the establishment of infrastructures intended to safeguard, protect and enhance heritage assets (UNESCO, 2014). "Raising awareness and education" covers measures and programmes intended to promote the educational potential of heritage and its transmission as well as informational and media programmes and facilities addressed to the general public and to key social agents in order to foster understanding, recognition, respect and enhancement of heritage in society (UNESCO, 2014). 
596 2.4.13. Social media communication (SMC)

597 Communication is an important tool for building support for protected areas, bringing 598 environmental awareness to the public and thus helping the achievement of conservation targets 599 (Hamú et al., 2004). In the case of MPAs, the media coverage of the activities performed and the 600 relative social-ecological benefits help connecting people to nature and promote the establishment 601 of trust, thus favouring compliance to MPA rules by users and stakeholders (López Ornat and 602 Vignes, 2015). Even if the MPA is not covered in TV, local radio, or other media, communicating 603 to the public is today possible by means of social networks (e.g., Facebook, Twitter), which provide 604 powerful and easily accessible global communication platforms. Through such channels, awareness 605 and education on environmental topics and conservation issues are not only desirable but probably 606 necessary.

607 The Social media communication (SMC) indicator assesses the ability of the MPA to engage users 608 in social networks. It is calculated as follows:

$$
\mathrm{SMC}=\sum_{\mathrm{i}=1}^{\mathrm{N}} \beta \frac{\mathrm{ER}_{\mathrm{i}}}{\mathrm{N}} \times 100
$$

609

where $E R_{i}$ is the engagement rate of the $i$-th social network, calculated as the ratio between the total engaged users (i.e., users that engaged with a post by clicking on, reacting to, commenting on, or sharing it) and the total reach (i.e., the number of users that found that post in the news feed); $\beta$ is the ER target, set to $1 \%$ (i.e., 1 user out of 100 that found a MPA post on the news feed engaged with it); $N$ is the total number of social media considered.

\subsection{Graphic output}

Results of the MOSE framework are presented through an adapted version of the OHI flower plots (Halpern et al., 2012). R scripts to generate flower plots were downloaded from the GitHub platform (https://github.com/OHI-Science/arc/blob/master/circle2016/plot_flower_local.R) and then modified to display REA and MaPA results. REA sub-indicators and MaPA indicators are represented as petals of the flower. Each petal area is filled according to its score and coloured in a traffic light gradient.

\subsection{Case study}

Located on the Catalan coast of Southern France, the Cerbère-Banyuls Natural Marine Reserve is one of the oldest MPAs of the Mediterranean. It was established in 1974 to protect the seabed and 
marine species and to sustainably manage human activities and development (Payrot et al., 2014).

629 The MPA aims at protecting local biodiversity and rare and threatened ecosystems as well as areas 630 valuable for geological or other natural features (www.blueparks.org). With an overall area of 6.5 $631 \mathrm{~km}^{2}$ and a $6 \mathrm{~km}$ coast length, the MPA is divided in two distinct protection zones, namely the fully 632 protected area $\left(0.65 \mathrm{~km}^{2}\right)$ and the partially protected area $\left(5.85 \mathrm{~km}^{2}\right)$, where different human uses 633 are allowed (Claudet et al. 2011) (Fig. 3). In the fully protected area, no human activity can occur 634 except from authorized scientific research. Instead, the partially protected area allows human 635 activities such as artisanal and recreational fishing, bathing, and scuba-diving, while others such as 636 spearfishing are prohibited. Scientific monitoring activities are routinely carried out throughout the 637 year, both inside and outside the MPA, also in collaboration with research laboratories 638 (www.blueparks.com).

639 The MPA was chosen as case study to test the applicability and potential usefulness of the MOSE 640 framework because of its management and remarkable conservation results, for which the MPA 641 was awarded with the Green List IUCN label in 2015 and the Global Ocean Refuge System status 642 in 2018 (recently renamed Blue Parks Awards). For these reasons, the MPA represented a suited 643 first application to try out the response of the MOSE framework against the social-ecological effectiveness and management performance of a successful MPA.

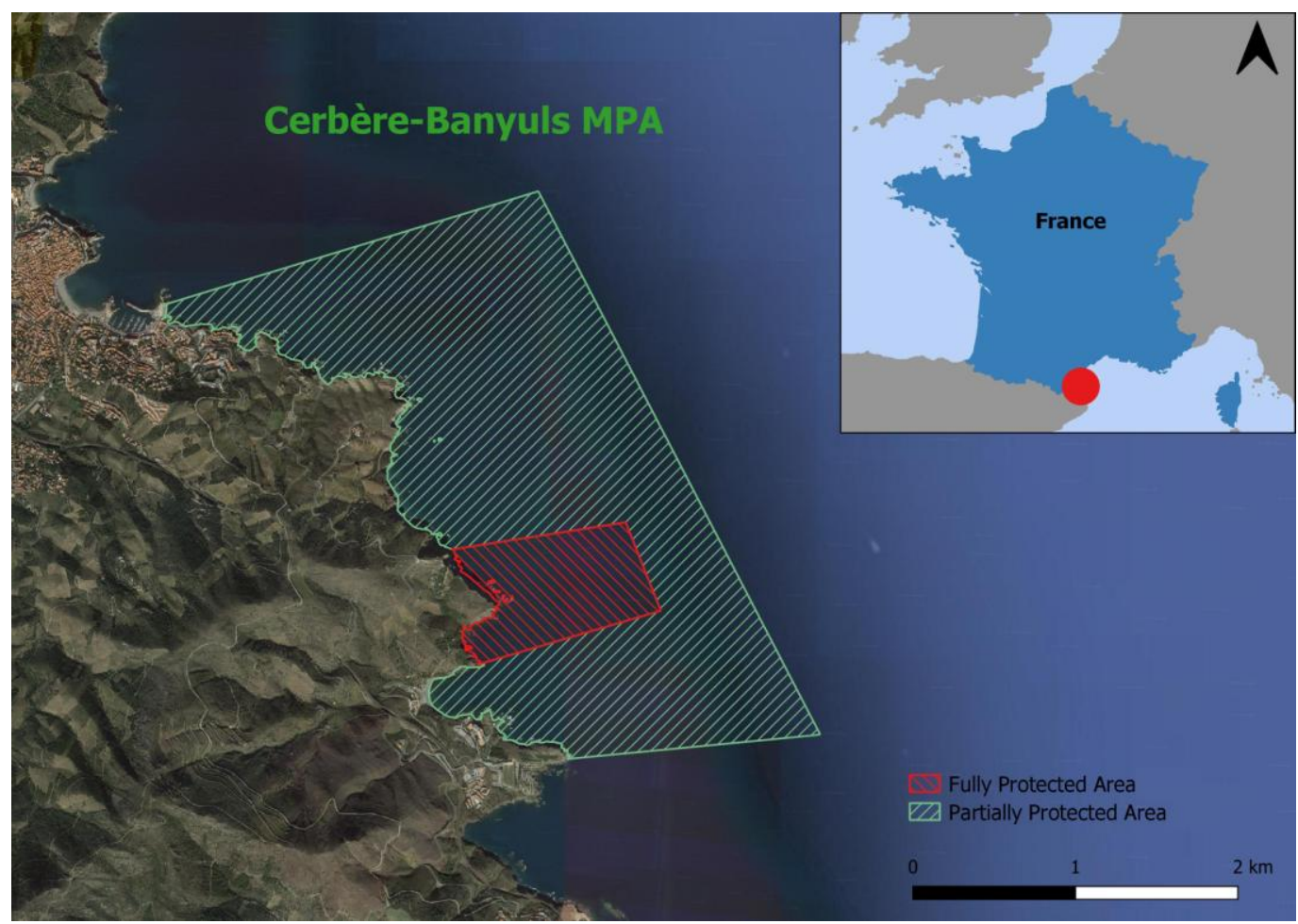

Figure 3. Cerbère-Banyuls Natural Marine Reserve. In the figure, the two protection zones of the MPA are shown: the fully protected area (red grid) and the partially protected area (green grid). 


\subsection{Data collection}

652

653

654

655

656

657

658

659

660

661

662

663

664

665

666

667

668

669

670

671

672

673

674

675

676

677

678

679

680

681

682

683

684

Data for calculating the REA and MaPA indices were collected through semi-structured surveys submitted to the reserve management body. These surveys allowed for the collection of management data, scientific literature, and reports produced over the last five years. The survey forms can be found in the Supplementary Information on-line material.

\section{Results}

The REA index calculated for the zone with the highest level of protection (i.e., the fully protected area) resulted in a score of 100 out of 100 , with all indicators assessed (DR $=100$ ) and a level of protection corresponding to the fully protected class $(\mathrm{PL}=2)$ (Fig. 4). The Fishing and the Local economy indicators as well as the Traditional activities sub-indicator were not assessed since they referred to activities that are not allowed in the investigated zone (not applicable $=$ NA). The assessed indicators Habitats, Species, and Charismatic species scored more than 100 (Fig. 4).

The partially protected area scored lower than the fully protected one, with an overall score of 83 and also a lower degree of reliability (DR = 87.5) (Fig. 4). The Protection Level $(P L)$ indicator scored 5, corresponding to the highly protected class. Industrial fishing and Natural products subindicators were not assessed because the relative activities are not allowed (NA), while Artisanal fishing lacked data (no data = ND). Among the four REA indicators, Biodiversity showed the highest score (100), followed by Cultural identity (85), Local economy (84), and Fishing (64), whose score was exclusively due to the Recreational fishing sub-indicator. The value of Habitats, Species, Livelihoods and Charismatic species sub-indicators resulted higher than 100, while Traditional activities and Tourism and recreation sub-indicators scored 70 and 69, respectively.

The REA index score for the whole MPA was calculated as the average of the REA scores of the two protection zones weighted by the area occupied by each zone in the MPA (Fig. 5). Overall, the MPA scored 85 with a higher reliability score $(\mathrm{DR}=92.3)$ than the partially protected area and a level of protection corresponding to the highly protected class $(\mathrm{PL}=4.7)$.

The MaPA index scored 90 out of 100 with a DR of 100 (Fig. 5). All indicators scored more than 60, and 3 of them (i.e., Information and awareness of regulations, Professionalism and competences, and Personnel stability) reached 100. Cultural heritage and Social media communication could not be assessed (NA) and therefore were not accounted for in the calculation of the DR. Professionalism and competences was the only MaPA indicator that scored more than 100. 


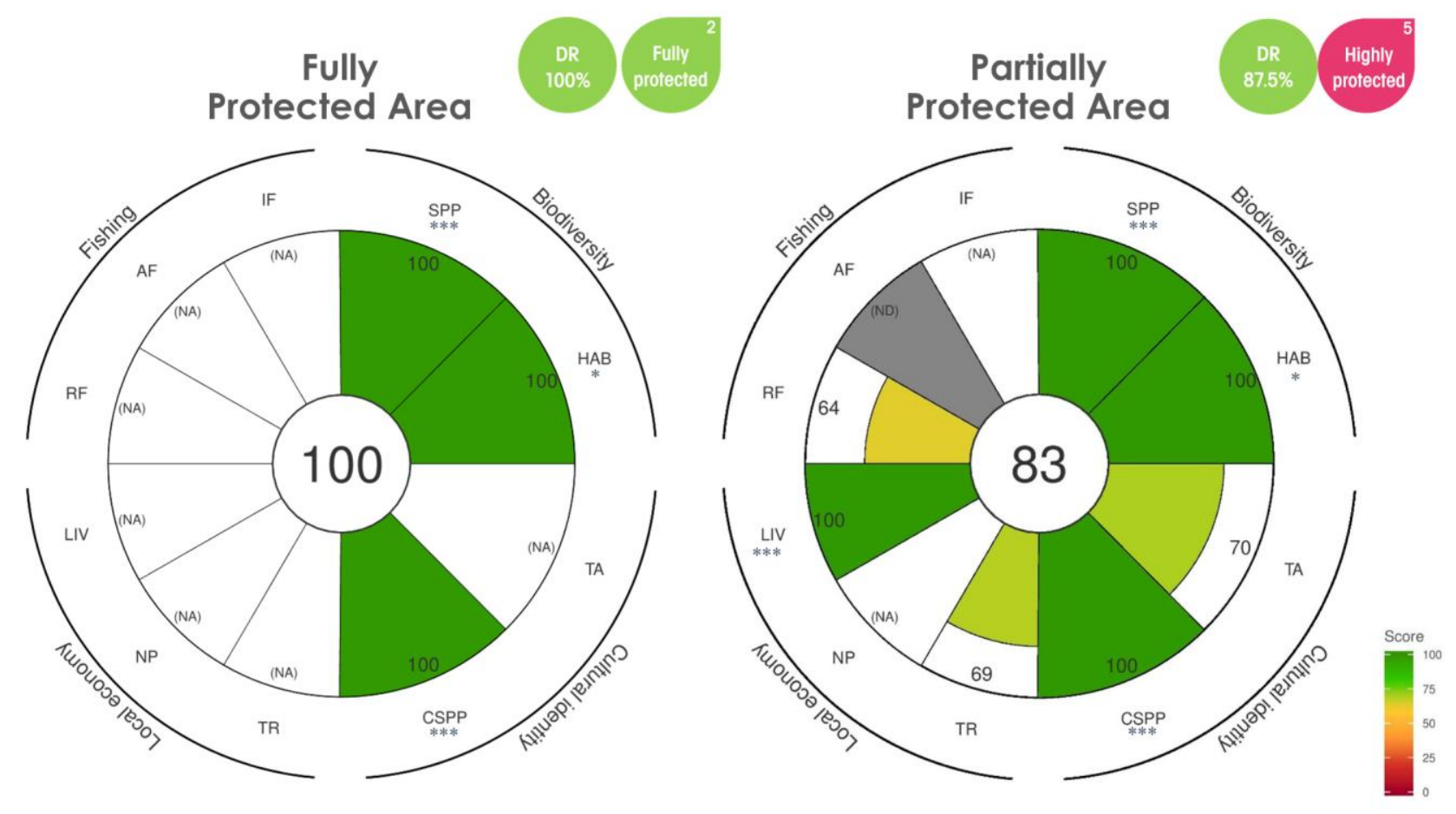

Figure 4. Reserve Effectiveness Assessment (REA) index calculated for the fully protected area (left panel) and the partially protected area (right panel). Each indicator is scored from 0 to 100 following a red-yellow-green colour gradient. On the top right of each plot, the scores of the Degree of reliability (DR) and Protection level (PL) indicators are also shown. Indicators scoring more than 100 are marked with the $*$ symbol $(*, 100<$ score<200; **, 200 $\leq$ score $<300 ; * * *$, score $\geq 300$ ).
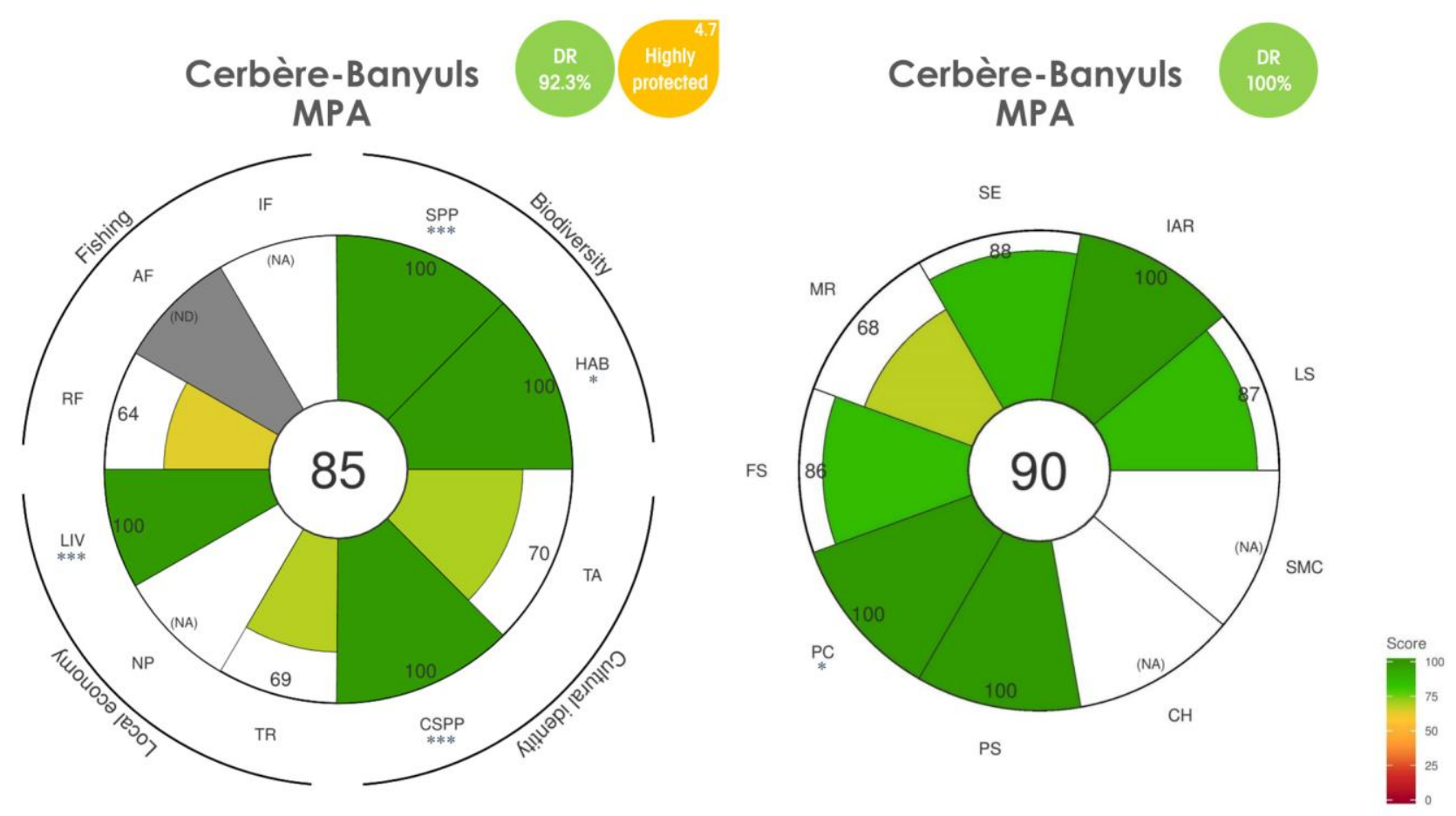

Figure 5. Reserve Effectiveness Assessment (REA) (left panel) and Management Performance Assessment (MaPA) (right panel) indices calculated for the Cerbère-Banyuls Natural Marine Reserve. Each indicator is scored from 0 to 100 following a red-yellow-green colour gradient. On the top right of each plot, the scores of the Degree of reliability (DR) and Protection level (PL) indicators are also shown. Indicators scoring more than 100 are marked with the * symbol (*, $100<$ score $<200 ; * *, 200 \leq$ score $<300 ; * * *$, score $\geq 300$ ). 


\section{Discussion}

The application of the MOSE framework showed that a high level of management effort is applied

702 to the Cerbère-Banyuls Natural Marine Reserve, generating several social-ecological benefits. 703 Almost all of the data required to implement the MOSE framework were available $\left(\mathrm{DR}_{\max }=100\right.$ and $704 \mathrm{DR}_{\min }=87.5$ ), with only the Artisanal fishing indicator lacking data. The REA results showed high 705 scores for all the assessed indicators in both protection zones $(\min =64 ; \max =100$; average $=83$ ), 706 in accordance to their Level of protection (i.e., fully and highly protected). Remarkable are the 707 Biodiversity, Charismatic species, and Livelihoods scores, reflecting the positive ecological effects 708 of the long-lasting conservation effort on habitats and species of the MPA and its consequent 709 attractiveness for divers. Such positive effects are not as evident for the Tourism and recreation 710 indicator, since tourism is highly developed in the whole region (www.cdt66-observatoire.com).

711 The MaPA index scored higher than REA $(\min =68$; $\max =100$; average $=90)$, with all applicable 712 indicators assessed ( $\mathrm{DR}=100)$. Cultural heritage and Social media communication indicators 713 could not be assessed (NA). Indeed, the reserve is not officially committed to the preservation of 714 local cultural aspects according to its mission. Moreover, it does not manage any social network, 715 which are instead managed by the Department of the Pyrenées-Orientales. Nevertheless, the reserve 716 is regularly requested by press and television but such media were not taken into account in the 717 Social media communication indicator. Professionalism and competences and Personnel stability 718 indicators scored both 100, highlighting the importance of a competent and stable staff. Such results 719 point to professionalism and working stability of the management body as two main drivers of 720 MPA success, allowing quality and continuity of conservation actions.

721 The choice of developing and applying a comprehensive but synthetic assessment framework was 722 taken to provide an overview of the overall level of success of MPAs. Although this first 723 application of the MOSE framework was able to highlight the overall success of the Cerbère724 Banyuls Reserve, further applications are needed to test its effectiveness and sensitivity. Such 725 applications should target a larger number and variety of MPAs, including differences in age of 726 establishment, size, geography (i.e., coastal vs island MPA), type (i.e., single- vs multi-use MPA), 727 and configuration (i.e., single MPA vs MPA network).

728 After this first application, strengths of the MOSE framework can be highlighted. Compared to 729 other assessment frameworks for MPAs (Tab. 1), the MOSE framework shows distinctive features. 730 As previously showed, most frameworks focus on one or few domains of assessment. The MOSE 731 framework instead integrates indicators referring to the ecological, social, economic, governance, 732 and management domains, covering all main areas of investigation for the assessment of MPAs 
733 effectiveness and performance. In addition, unlike other frameworks, it is able to provide 734 quantitative results, which are synthetically displayed through an intuitive graphical output that simplifies their communication. Graphical representations of results (Fig. 4 and 5) carry indeed remarkable communicative power as they are able to easily provide a quantitatively comparable measure of the degree to which MPAs meet their goals. Flower plots show results at index score level (synthetic information) and indicators score level (detailed information). Such feature is especially useful when conveying information on effectiveness and performance to politicians, decision-makers, and other stakeholders. In addition, the communication of results is strengthened by the information on the reliability of the overall scores of the two indices. Its inclusion gives a measure of their consistency while providing itself an evaluation on the data gap to implement adaptive management strategies. Another strength of the MOSE framework is represented by the fact that the investigation scale matches the scale at which decisions are made. MPAs are legally empowered to regulate human activities inside their borders, which makes system-level assessments - such as the MOSE framework - particularly effective in informing management actions through feedback adaptive loops to meet marine conservation and sustainability goals. Finally, the development of the MOSE framework is timely. MPAs are playing an important role in international strategies for ocean sustainability. Currently, these strategies focus mainly on increasing the coverage of MPAs worldwide without paying enough attention to their actual effectiveness, which is a fundamental point to achieve the pursued sustainability objectives. Science-based and quantitative informative tools to support the adaptive management process of MPAs are needed to fill this gap. The MOSE framework makes an attempt towards this direction, providing a tool to support managers of MPAs all over the world in targeting and assessing local social-ecological benefits and management efforts. Indeed, like in the case of the Ocean Health Index (Halpern et al., 2012), MOSE is a flexible assessment framework allowing for adaptability towards context-related necessities and peculiarities. New indicators can be added and changes can be applied to the existing ones, depending for instance on the MPA mission and objectives. Nonetheless, consistency is one of the main strengths of system scale assessment frameworks and major modifications could compromise the comparability of results among different MPAs and for the same MPA over time. Finally, as previously stated, REA indicators measure the socialecological benefits that MPAs provide to local communities. Defining such effects as benefits provided by marine natural capital matches the notion of "ecosystem services" internationally recognized and fostered by several initiatives such as the Millennium Ecosystem Assessment (MA), The Economics of Ecosystems and Biodiversity (TEEB), and the Intergovernmental Science-Policy Platform on Biodiversity and Ecosystem Services (IPBES). REA indicators can be also linked to the 
United Nations SDGs supported by MPAs, providing a quantitative measure of their local support to global sustainability goals (Fig. 6).

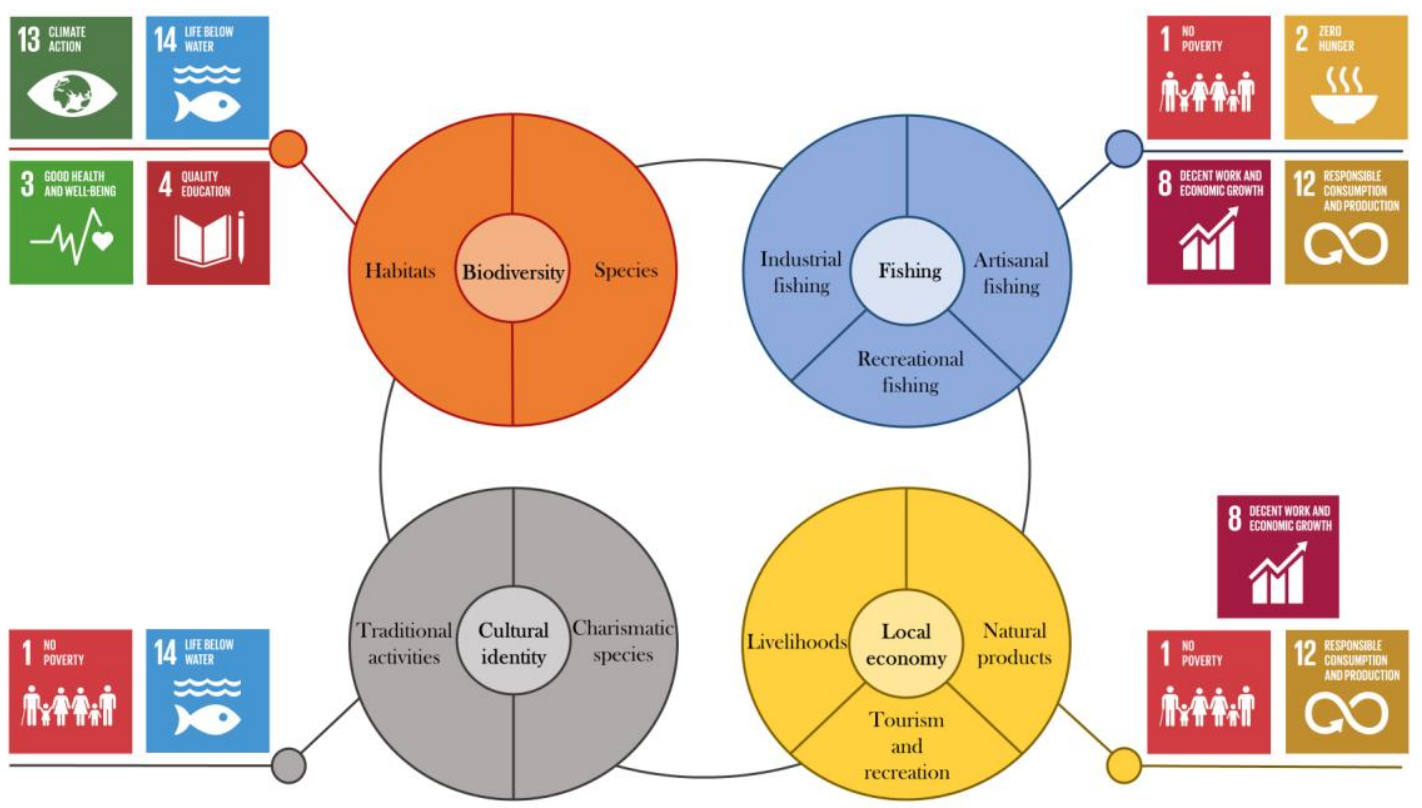

Figure 6. Links between the REA indicators of the MOSE framework and UN-SDGs.

Along with the strengths of the MOSE framework, the following aspects should be carefully considered. The use of a 0-100 scale is well suited in the case of target values which represent the full achievement of the objective that is measured. This is the case of the MaPA indicators, whose scores indicate the degree to which their targets are met. On the contrary, the calculation method of the REA index uses values of measured variables from control areas as reference points for the absence of protection. Hence, the reference points of REA indicators do not represent target values, but rather the threshold beyond which measuring the reserve effect. This difference between REA and MaPA approaches needs to be taken into account when interpreting the results of the two indices. Another aspect to be considered is that the high amount of data required to implement the MOSE framework could represent an obstacle to its applicability. Despite the presence of the Degree of reliability $(D R)$ indicator (which can cope with the lack of data addressing the level of assessment comprehensiveness), missing substantial information could compromise the application of the framework and the meaningfulness of the overall REA and MaPA scores. Nevertheless, the verified lack of data represents a result itself as it can inform the adaptive management process and provide useful directions on data to be collected and studies to be carried out. Finally, the 
multicriteria feature of the MOSE framework requires the capability of dealing with a multitude of socio-economic and ecological data to be managed and interpreted.

\section{Concluding remarks}

In this study, a novel integrated framework measuring the overall success of MPAs was presented. The case study of the Cerbère-Banyuls Natural Marine Reserve was implemented to test its applicability and potential usefulness as a tool to support managers and decision-makers in charge for developing nature conservation strategies. These strategies should be based on the application of adaptive management processes requiring multicriteria assessment frameworks and synthetic indices able to capture the complexity of marine social-ecological systems. Future applications of the MOSE framework will allow improving its applicability while contributing to establish a comparative assessment among MPAs at local, national, and larger scales.

\section{Acknowledgements}

We are grateful to all those CRIOBE laboratory members that provided constructive feedback on the study. Special thanks go to Rodolphe Devillers for his suggestions and to Jérémy Carlot for his support with R programming. Finally, we also wish to thank Virginie Hartmann of the CerbèreBanyuls Natural Marine Reserve, who provided essential information for the implementation of the case study.

\section{References}

Adger, W.N., Hughes, T.P., Folke, C., Carpenter, S.R., Rockström, J., 2005. Social-Ecological Resilience to Coastal Disasters. Science, 1-6. http://doi.org/10.1126/science.1112122

Agardy, T., Claudet, J., Day, J.C., 2016. 'Dangerous Targets' revisited: Old dangers in new contexts plague https://doi.org/10.1002/aqc. 2675

Alban, F., Boncoeur, J., Roncin, N., 2011. Assessing the impact of marine protected areas on society's well-being: an economic perspective. In: Marine Protected Areas - A Multidisciplinary Approach. Cambridge University Press, Cambridge, UK, pp. 226-246.

Angulo-Valdés, J. A., \& Hatcher, B. G. (2010). A new typology of benefits derived from marine protected areas. Marine Policy, 34(3), 635-644.

Arias, A., 2015. Understanding and managing compliance in the nature conservation context. Journal of Environmental Management 153, 134-143. https://doi.org/10.1016/j.jenvman.2015.02.013

Arias, A., Pressey, R.L., Jones, R.E., Álvarez-Romero, J.G., Cinner, J.E., 2016. Optimizing enforcement and compliance in offshore marine protected areas: A case study from Cocos Island, Costa Rica. Oryx, 50(1), 18-26. https://doi.org/10.1017/S0030605314000337 
Ban, N.C., Gurney, G.G., Marshall, N.A., Whitney, C.K., Mills, M., Gelcich, S., et al., 2019. Well-being outcomes of marine protected areas. Nature Sustainability, 2(6), 524-532.

Barbier, E.B., 2017. Marine ecosystem services. Current Biology, 27(11), R507-R510.

Beger, M., Harborne, A.R., Dacles, T.P., Solandt, J.L., Ledesma, G.L., 2004. A framework of lessons learnt from community-based marine reserves and its effectiveness in guiding a new coastal management initiative in the Philippines. Environmental Management, 34, 786-801.

Bennett, N.J., Dearden, P., 2014. From measuring outcomes to providing inputs: Governance, management, and local development for more effective marine protected areas. Marine Policy, 50(PA), 96-110.

Bennett, N.J., Roth, R., Klain, S.C., Chan, K., Christie, P., Clark, D.A., et al., 2017. Conservation social science: Understanding and integrating human dimensions to improve conservation. Biological Conservation, 205, 93108.

Berkes, F., 2011. Restoring Unity, in: World Fisheries. Wiley-Blackwell, Oxford, UK, pp. 9-28.

Beukering, P. Van, Scherl, L.M., Smith, S., Hale, L., Purvis, N., 2014. How Marine Protected Areas contribute to poverty reduction. Monographs of the Society for Research in Child Development, 79(1), 141-141.

Binet, T., Diazabakana, A., Hernandez, S., 2015. Sustainable financing of Marine Protected Areas in the Mediterranean: a financial analysis. Vertigo Lab, MedPAN, RAC/SPA, WWF Mediterranean. 114 pp.

Borja, A., Ranasinghe, A., Weisberg, S.B., 2009. Assessing ecological integrity in marine waters, using multiple indices and ecosystem components: Challenges for the future. Marine Pollution Bulletin, 59(1-3), 1-4.

Buonocore E., Picone F., Russo G.F., Franzese P.P., 2018. The Scientific Research On Natural Capital: A Bibliometric Network Analysis. Journal of Environmental Accounting and Management 6(4), 374-384.

Buonocore, E., Picone, F., Donnarumma, L., Russo, G.F., Franzese, P.P., 2019. Modeling matter and energy flows in marine ecosystems using emergy and eco-exergy methods to account for natural capital value. Ecological Modelling, 392.

Cardinale, B.J., Duffy, J.E., Gonzalez, A., Hooper, D.U., Perrings, C., Venail, P., et al., 2012. Biodiversity loss and its impact on humanity. Nature, 486(7401), 59-67.

CBD Secretariat. 2011. Strategic Plan for Biodiversity 2011-2020: Further Information Related to the Technical Rationale for the Aichi Biodiversity Targets, Including Potential Indicators and Milestones. UNEP/CBD/COP/10/INF/12/Rev.1. 14/03/2011.

Charles, A., 2012. People, oceans and scale: Governance, livelihoods and climate change adaptation in marine social-ecological systems. Current Opinion in Environmental Sustainability, 4, 351-357.

Christie, P., 2004. Marine protected areas as biological successes and social failures in Southeast Asia. American Fisheries Society Symposium, 2004(42), 155-164.

Claudet, J., (ed.) 2011. Marine Protected Areas: Effects, networks and monitoring - A multidisciplinary approach, Cambridge University Press, Cambridge, UK.

Claudet, J., 2018. Six conditions under which MPAs might not appear effective (when they are). ICES Journal of Marine Science, 75(3), 1172-1174.

Claudet, J., 2019. France must impose strict levels of marine protection. Nature, 570, 36.

Claudet, J., Bopp, L., Cheung, W. W. L., Devillers, R., Escobar-Briones, E., Haugan, P., et al., 2020. A Roadmap for Using the UN Decade of Ocean Science for Sustainable Development in Support of Science, Policy, and Action. One Earth, 2(1), 34-42. 
Claudet, J., García-Charton, J.A., Lenfant, P., 2011. Combined Effects of Levels of Protection and Environmental Variables at Different Spatial Resolutions on Fish Assemblages in a Marine Protected Area. Conservation Biology, 25(1), 105-114.

Claudet, J., Guidetti, P., 2010. Fishermen contribute to protection of marine reserves. Nature, 464(7289), 673.

Claudet, J., Guidetti, P., 2010. Improving assessments of marine protected areas. Aquatic Conservation: Marine and Freshwater Ecosystems, 20(2), 239-242.

Coll, M., Cury, P., Azzurro, E., Bariche, M., Bayadas, G., Bellido, J.M., et al., 2013. The scientific strategy needed to promote a regional ecosystem-based approach to fisheries in the Mediterranean and Black Seas. Reviews in Fish Biology and Fisheries, 23, 415-434.

Dalton, R., 2010. Reserves 'win-win' for fish and fishermen. Nature, 463, 1007.

Devillers, R., Lemieux, C.J., Gray, P.A., Claudet, J., 2019. Canada's uncharted conservation approach. Science, 364 (6447), 1243.

Di Franco, A., Bussotti, S., Navone, A., Panzalis, P., Guidetti, P., 2009. Evaluating effects of total and partial restrictions to fishing on Mediterranean rocky-reef fish assemblages. Marine Ecology Progress Series, 387, 275285.

Di Franco, A., Thiriet, P., Di Carlo, G., Dimitriadis, C., Francour, P., Gutiérrez, N.L., et al., 2016. Five key attributes can increase marine protected areas performance for small-scale fisheries management. Scientific Reports, 6(December), 1-9.

Ducarme, F., Luque, G.M., Courchamp, F., 2013. What are "charismatic species" for conservation biologists? BioSciences Master Reviews, 3, 8.

Durham E., Baker H., Smith M., Moore E., Morgan V., 2014. The BiodivERsA Stakeholder Engagement Handbook. BiodivERsA, Paris (108 pp).

Edgar, G.J., Stuart-Smith, R.D., Willis, T.J., Kininmonth, S., Baker, S.C., Banks, S., et al., 2014. Global conservation outcomes depend on marine protected areas with five key features. Nature, 506, 216-220.

European Commission, 2018. Study on the economic benefits of Marine Protected Areas. Literature review analysis. $147 \mathrm{pp}$.

European Union, 2000. Water Framework Directive. Directive 2000/60/CE of the European Parliament and Council of 23 October 2000. $\mathrm{N}^{\circ}$ L 327, 22/12/2000.

European Union, 2008. Marine Strategy Framework Directive. Directive 2008/56/EC of the European Parliament and of the Council of 17 June 2008 establishing a framework for community action in the field of marine environmental policy. $\mathrm{N}^{\circ} \mathrm{L} 164,25 / 06 / 2008.22 \mathrm{p}$.

FAO, 2016. The State of World Fisheries and Aquaculture 2016. Contributing to food security and nutrition for all. Rome. 200 pp

Filbee-Dexter, K., Scheibling, R., 2014. Sea urchin barrens as alternative stable states of collapsed kelp ecosystems. Marine Ecology Progress Series, 495, 1-25.

Franzese P.P., Liu G., Aricò S., 2019. Environmental accounting models and nature conservation strategies. Ecological Modelling 397, 36-38.

Franzese, P.P., Buonocore, E., Donnarumma, L., Russo, G.F., 2017. Natural capital accounting in marine protected areas: The case of the Islands of Ventotene and S. Stefano (Central Italy). Ecological Modelling, 360, 290-299. 
Franzese, P.P., Buonocore, E., Paoli, C., Massa, C., Stefano, D., Fanciulli, et al., 2015. Environmental Accounting in Marine Protected Areas: the EAMPA Project. Journal of Environmental Accounting and Management, 3(4), 324-332.

Gallacher, J., Simmonds, N., Fellowes, H., Brown, N., Gill, N., Clark, W., et al., 2016. Evaluating the success of a marine protected area: A systematic review approach. Journal of Environmental Management, 183, 280-293.

Galzin, R., Crec'hriou, R., Lenfant, P., Planes, S., 2004. Marine protected areas: a laboratory for scientific research. Revue d'e'cologiedla Terre et la Vie 59 (1e2), $37 \mathrm{e} 48$.

Garcia, S.M., Zerbi, A., Aliaume, C., Do Chi, T., Lasserre, G., 2003. The ecosystem approach to fisheries. Issues, terminology, principles, institutional foundations, implementation and outlook. FAO Fisheries Technical Paper. No. 443. Rome, FAO. 2003. 71 p.

Gee, K., Kannen, A., Adlam, R., Brooks, C., Chapman, M., Cormier, R., et al., 2017. Identifying culturally significant areas for marine spatial planning. Ocean \& Coastal Management 136, 139-147.

Giakoumi, S., McGowan, J., Mills, M., Beger, M., Bustamante, R.H., Charles, A., et al., 2018. Revisiting "Success" and "Failure" of Marine Protected Areas: A Conservation Scientist Perspective. Frontiers in Marine Science, 5(June), 223.

Gill, D.A., Mascia, M.B., Ahmadia, G.N., Glew, L., Lester, S. E., Barnes, M., et al., 2017. Capacity shortfalls hinder the performance of marine protected areas globally. Nature, 543(7647), 665-669.

Guidetti, P., 2002. The importance of experimental design in detecting the effects of protection measures on fish in Mediterranean MPAs. Aquatic Conservation: Marine and Freshwater Ecosystems, 12, 619-634.

Guidetti, P., 2006. Marine Reserves Reestablish Lost Predatory Interactions and Cause Community Changes in Rocky Reefs. Bulletin Ecological Society of America, 16, 963-976.

Guidetti, P., Baiata, P., Ballesteros, E., Di Franco, A., Hereu, B., Macpherson, E., et al., 2014. Large-Scale Assessment of Mediterranean Marine Protected Areas Effects on Fish Assemblages. PLoS One, 9, e91841.

Guidetti, P., Bussotti, S., Pizzolante, F., Ciccolella, A., 2010. Assessing the potential of an artisanal fishing comanagement in the Marine Protected Area of Torre Guaceto (southern Adriatic Sea, SE Italy). Fisheries Research, 101(3), 180-187.

Guidetti, P., Milazzo, M., Bussotti, S., Molinari, A., Murenu, M., Pais, A., et al., 2008. Italian marine reserve effectiveness: Does enforcement matter? Biological Conservation, 141, 699-709.

Halpern, B.S., Longo, C., Hardy, D., McLeod, K.L., Samhouri, J.F., Katona, S.K., et al., 2012. An index to assess the health and benefits of the global ocean. Nature, 488, 615-620.

Halpern, B.S., Warner, R.R., 2002. Marine reserves have rapid and lasting effects. Ecology Letters, 5, 361-366.

Hamú, D., Auchincloss, E., Goldstein, W., 2004. Communicating Protected Areas. Commission on Education and Communication, IUCN, Gland, Switzerland and Cambridge, UK. xiv + 312 pp.

Harmelin-Vivien, M., Harmelin, J.G., Chauvet, C., Duval, C., Galzin, R., Lejeune, P., et al., 1985. Evaluation visuelle des peuplements et populations de poissons. Méthodes et problémes. Revue d'Écologie - la Terre et la Vie, 40, 467-539.

Herr, D., Landis, E., 2016. Coastal blue carbon ecosystems. Opportunities for Nationally Determined Contributions. Policy Brief. Gland, Switzerland: IUCN and Washington, DC, USA: TNC.

Hockings, M., Leverington, F., Cook, C., 2015. 'Protected area management effectiveness', in G. L. Worboys, M. Lockwood, A. Kothari, S. Feary and I. Pulsford (eds) Protected Area Governance and Management, pp. 889-928, ANU Press, Canberra. 
Hogg, K., Noguera-Méndez, P., Semitiel-García, M., \& Giménez-Casalduero, M. (2013). Marine protected area governance: Prospects for co-management in the European Mediterranean. Advances in Oceanography and Limnology, 4(2), 241-259.

Horigue, V., Aliño, P.M., Pressey, R.L., 2014. Evaluating management performance of marine protected area networks in the Philippines. Ocean \& Coastal Management, 95, 11-25.

Horta e Costa, B., Claudet, J., Franco, G., Erzini, K., Caro, A., Gonçalves, E.J., 2016. A regulation-based classification system for Marine Protected Areas (MPAs). Marine Policy, 72, 192-198.

IOC-UNESCO, 2017. Global Ocean Science Report - The current status of ocean science around the world. L. Valdés et al. (eds), Paris, UNESCO Publishing.

IUCN WCPA, 2018. Applying IUCN's Global Conservation Standards to Marine Protected Areas (MPA). Delivering effective conservation action through MPAs, to secure ocean health \& sustainable development. Version 1.0. Gland, Switzerland. 4pp.

Jones, P.J.S., Murray, R.H., Vestegaard, O., 2019. Enabling Effective and Equitable Marine Protected Areas guidance on combining governance approaches. UN Environment.

Kolding, J., Béné, C., Bavinck, M., 2014. Small-scale fisheries-importance, vulnerability, and deficient knowledge. Chapter 22. In Governance for marine fisheries and biodiversity conservation. Interaction and coevolution. Edited by S. Garcia, J. Rice, and A. Charles. Wiley-Blackwell. pp. 317-331.

Laffoley, D., Baxter, J.M., (editors), 2016. Explaining ocean warming: Causes, scale, effects and consequences. Full report. Gland, Switzerland: IUCN. 456 pp.

Leenhardt, P., Low, N., Pascal, N., Micheli, F., Claudet, J., 2015a. The Role of Marine Protected Areas in Providing Ecosystem Services, in: Aquatic Functional Biodiversity, 211-239.

Leenhardt, P., Teneva, L., Kininmonth, S., Darling, E., Cooley, S., Claudet, J., 2015b. Challenges, insights and perspectives associated with using social-ecological science for marine conservation. Ocean \& Coastal Management, 115, 49-60.

López Ornat A., Vignes P., 2015. Surveillance and enforcement of regulations in Mediterranean MPAs, Practical guide. RAC/SPA, Port-Cros National Park, National Marine Park of Zakynthos. MedPAN Collection. 40 pp.

López-Angarita, J., Moreno-Sánchez, R., Maldonado, J.H., Sánchez, J.A., 2014. Evaluating linked socialecological systems in marine protected areas. Conservation Letters, 7, 241-252.

Marine Protected Areas Support Network, Marine Protected Area Management Effectiveness Assessment Tool (MPA MEAT). Coral Triangle Support Partnership of USAID, Department of Environment and Natural Resources, MPA Support Network Philippines, Quezon City, Philippines, 2010.

Mascia, M. B., 2004. Social dimensions of marine reserves. In Sobel J. and Dahlgren, C. (eds.) Marine reserves: a guide to science, design, and use, pp 164-186. Washington: Island Press.

Mascia, M.B., Claus, C.A., Naidoo, R., 2010, Impacts of Marine Protected Areas on Fishing Communities. Conservation Biology, 24: 1424-1429.

Millennium Ecosystem Assessment, 2005. Ecosystems and Human Well Being: Synthesis. Island Press, Washington DC.

Nellemann, C., Corcoran, E., Duarte, C. M., Valdés, L., De Young, C., Fonseca, L., Grimsditch, G. (Eds), 2009. Blue Carbon. A Rapid Response Assessment. United Nations Environment Programme, GRID-Arendal, www.grida.no 
Ocean Health Index, 2016. ohi-global version: Global scenarios data for Ocean Health Index, [04/2019]. National Center for Ecological Analysis and Synthesis, University of California, Santa Barbara. Available at: https://github.com/OHI-Science/ohi-global/releases

Ojea E., Pascual, M., March, D., Bitetto, I., Melià, P., Breil, M., et al., 2017. Socioeconomic impacts of networks of Marine Protected Areas. In: Management of Marine Protected Areas: A Network Perspective, First Edition. John Wiley \& Sons Ltd. Published 2017 by John Wiley \& Sons Ltd. p. 103-124.

Ojeda-Martinez, C., Gimenez Casalduero, F., Bayle-Sempere, J.T., Barbera Cebrian, C., Valle, C., SanchezLizaso, L., et al., 2009. A conceptual framework for the integral management of marine protected areas. Ocean \& Coastal Management, 52 (2), 89-10.

Otero, M., Garrabou, J. and Vargas, M., 2013. Mediterranean Marine Protected Areas and climate change: A guide to regional monitoring and adaptation opportunities. Malaga, Spain: IUCN.

Pascual, M., Rossetto, M., Ojea, E., Milchakova, N., Giakoumi, S., Kark, S., et al., 2016. Socioeconomic impacts of marine protected areas in the Mediterranean and Black Seas. Ocean \& Coastal Management, 133(December), $1-10$.

Pauna V.H., Picone F., Le Guyader G., Buonocore E., Franzese P.P., 2018. The scientific research on ecosystem services: A bibliometric analysis. Ecological Questions 29 (3), 53-62.

Payrot, J., et al., 2014. Plan de gestion 2015-2019 de la RNMCB - section A - diagnostic de la RNMCB. Conseil Général des Pyrénées-Orientales, French: p. 14, English translation: p. 12.

Pelletier, D., 2011. INDICATORS - Constructing and validating indicators of the effectiveness of marine protected areas. In J. Claudet (Ed.), Marine Protected Areas (pp. 247-290).

Pelletier, D., García-Charton, J.A., Ferraris, J., David, G., Thébaud, O., Letourneur, Y., et al., 2005. Designing indicators for assessing the effects of marine protected areas on coral reef ecosystems: A multidisciplinary standpoint. Aquatic Living Resources, 18(1), 15-33.

Pelletier, D., García-Charton, J.A., Ferraris, J., David, G., Thébaud, O., Letourneur, Y., et al., 2005. Designing indicators for assessing the effects of marine protected areas on coral reef ecosystems: A multidisciplinary standpoint. Aquatic Living Resources, 18(1), 15-33.

Picone, F., Buonocore, E., D’Agostaro, R., Donati, S., Chemello, R., Franzese, P.P., 2017. Integrating natural capital assessment and marine spatial planning: A case study in the Mediterranean sea. Ecological Modelling, 361.

Pollnac, R., Christie, P., Cinner, J.E., Dalton, T., Daw, T.M., Forrester, G.E., et al., 2010. Marine reserves as linked social-ecological systems. Proceedings of the National Academy of Sciences, 107, 18262-18265.

Pomeroy, R.S., Watson, L.N., Parks, J.E., Gonzola, C.A., 2005. How is your MPA doing? a methodology for evaluating the management effectiveness of marine protected areas. Ocean \& Coastal Management 48 (7e8), $485 \mathrm{e} 502$.

Prato, G., Guidetti, P., Bartolini, F., Mangialajo, L., Francour, P., 2013. The importance of high-level predators in marine protected area management: Consequences of their decline and their potential recovery in the Mediterranean context. Advances in Oceanography and Limnology, 4, 176-193.

Rasheed, A. R. (2020). Marine protected areas and human well-being - A systematic review and recommendations. Ecosystem Services, 41(November 2018), 101048.

Rodríguez-Rodríguez, D., Rees, S.E., Rodwell, L.D., Attrill, M.J., 2015. Assessing the socioeconomic effects of multiple-use MPAs in a European setting: A national stakeholders' perspective. Environmental Science and Policy, 48, 115-127. 
Roncin, N., Alban, F., Charbonnel, E., Crec'hriou, R., de la Cruz Modino, R., Culioli, J.M., et al., 2008. Uses of ecosystem services provided by MPAs: How much do they impact the local economy? A southern Europe perspective. Journal for Nature Conservation, 16(4), 256-270.

Russ, G. R., Alcala, A. C., Maypa, A. P., Calumpong, H. P., \& White, A. T. (2004). Marine reserve benefits local fisheries. Ecological Applications, 14(2), 597-606.

Scianna, C., Niccolini, F., Bianchi, C. N., Guidetti, P., 2018. Applying organization science to assess the management performance of Marine Protected Areas: An exploratory study. Journal of Environmental Management 223(May), 175-184.

Scianna, C., Niccolini, F., Gaines, S. D., Guidetti, P., 2015. "Organization Science": A new prospective to assess marine protected areas effectiveness. Ocean \& Coastal Management, 116, 443-448.

Scianna, C., Niccolini, F., Giakoumi, S., Di Franco, A., Gaines, S.D., Bianchi, C.N., et al., 2019. Organization Science improves management effectiveness of Marine Protected Areas. Journal of Environmental Management, 240(March), 285-292.

Simard, F., Laffoley, D., Baxter, J.M., 2016. Marine Protected Areas and Climate Change: Adaptation and Mitigation Synergies, Opportunities and Challenges. Gland, Switzerland: IUCN. 52 pp

Steffen, W., Persson, Å., Deutsch, L., Zalasiewicz, J., Williams, M., Richardson, K., et al., 2011. The Anthropocene: From Global Change to Planetary Stewardship. Ambio 40, 739-761.

Sterling, E.J., Betley, E., Sigouin, A., Gomez, A., Toomey, A., Cullman, G., et al., 2017. Assessing the evidence for stakeholder engagement in biodiversity conservation. Biological Conservation, 209, 159-171.

Stolton, S., Hockings, M., Dudley, N., MacKinnon, K., Whitten, T., Leverington, F., 2007. 'Reporting Progress in Protected Areas A Site-Level Management Effectiveness Tracking Tool: second edition.' World Bank/WWF Forest Alliance published by WWF, Gland, Switzerland.

UNEP-WCMC, IUCN, NGS, 2018. Protected Planet Report 2018. UNEP-WCMC, IUCN and NGS: Cambridge UK; Gland, Switzerland; and Washington, D.C., USA.

UNESCO, 2014. Culture for Development Indicators: Methodology Manual. Paris: UNESCO Publishing. United Nations, 2015. Transforming Our World: The 2030 Agenda for Sustainable Development. New York: UN Publishing.

Unsworth, R.K.F., Cullen, L.C., Pretty, J.N., Smith, D.J., Bell, J.J., 2010. Economic and subsistence values of the standing stocks of seagrass fisheries: Potential benefits of no-fishing marine protected area management. Ocean and Coastal Management, 53(5-6), 218-224.

Vihervaara P., Franzese P.P., Buonocore E., 2019. Information, energy, and eco-exergy as indicators of ecosystem complexity. Ecological Modelling, 395, 23-27.

Winter, K.B., Lincoln, N.K., Berkes, F., 2018. The social-ecological keystone concept: A quantifiable metaphor for understanding the structure, function, and resilience of a biocultural system. Sustainability (Switzerland), $10(9)$.

Worm, B., Barbier, E.B., Beaumont, N., Duffy, J.E., Folke, C., Halpern, B.S., et al., 2006. Impacts of Biodiversity Loss on Ocean Ecosystem Services. Science (80), 314, 787-790.

Zupan, M., Bulleri, F., Evans, J., Fraschetti, S., Guidetti, P., Garcia-Rubies, A., et al., 2018a. How good is your marine protected area at curbing threats? Biological Conservation, 221(August 2017), 237-245.

Zupan, M., Fragkopoulou, E., Claudet, J., Erzini, K., Horta e Costa, B., Gonçalves, E.J., 2018b. Marine partially protected areas: drivers of ecological effectiveness. Frontiers in Ecology and the Environment, 16(7), 381-387. 